\title{
Mitochondrial ATP-Dependent Proteases-Biological Function and Potential Anti-Cancer Targets
}

\author{
Yue Feng ${ }^{1,2,+}$, Kazem Nouri $^{1,+}+\mathbb{D}$ and Aaron D. Schimmer ${ }^{1,2, *}$ \\ 1 Princess Margaret Cancer Centre, University Health Network, Toronto, ON M5G 1L7, Canada; \\ yue.feng@mail.utoronto.ca (Y.F.); Kazem.nouri@uhnresearch.ca (K.N.) \\ 2 Department of Medical Biophysics, University of Toronto, Toronto, ON M5G 1L7, Canada \\ * Correspondence: aaron.schimmer@uhn.ca; Tel.: +1-416-946-4501 (ext. 3996) \\ + These authors equally contributed to this work.
}

check for updates

Citation: Feng, Y.; Nouri, K.;

Schimmer, A.D. Mitochondrial ATP-Dependent ProteasesBiological Function and Potential Anti-Cancer Targets. Cancers 2021, 13, 2020. https://doi.org/10.3390/ cancers 13092020

Academic Editor: Jennifer S. Carew

Received: 16 March 2021

Accepted: 18 April 2021

Published: 22 April 2021

Publisher's Note: MDPI stays neutral with regard to jurisdictional claims in published maps and institutional affiliations.

Copyright: (C) 2021 by the authors Licensee MDPI, Basel, Switzerland. This article is an open access article distributed under the terms and conditions of the Creative Commons Attribution (CC BY) license (https:// creativecommons.org/licenses/by/ $4.0 /)$.
Simple Summary: Alterations of cellular metabolism and bioenergetics, oxidative stress, and intracellular reactive oxygen species (ROS) levels are hallmarks of cancer development. Mitochondrial proteases, especially ATP-dependent proteases are essential to regulate mitochondrial function by maintaining protein quality. Emerging studies suggest the therapeutic potential of targeting the matrix ATP-dependent protease ClpXP for a subset of malignancies. In this review, we summarize our current knowledge on the biological function and the anticancer effects of targeting ATP-dependent proteases with a focus on ClpXP.

Abstract: Cells must eliminate excess or damaged proteins to maintain protein homeostasis. To ensure protein homeostasis in the cytoplasm, cells rely on the ubiquitin-proteasome system and autophagy. In the mitochondria, protein homeostasis is regulated by mitochondria proteases, including four core ATP-dependent proteases, m-AAA, i-AAA, LonP, and ClpXP, located in the mitochondrial membrane and matrix. This review will discuss the function of mitochondrial proteases, with a focus on ClpXP as a novel therapeutic target for the treatment of malignancy. ClpXP maintains the integrity of the mitochondrial respiratory chain and regulates metabolism by degrading damaged and misfolded mitochondrial proteins. Inhibiting ClpXP genetically or chemically impairs oxidative phosphorylation and is toxic to malignant cells with high ClpXP expression. Likewise, hyperactivating the protease leads to increased degradation of ClpXP substrates and kills cancer cells. Thus, targeting ClpXP through inhibition or hyperactivation may be novel approaches for patients with malignancy.

Keywords: mitochondria; cancer; protease; ClpXP; AML

\section{Introduction}

Mitochondria are vital membrane-bound organelles in the cytoplasm of almost all eukaryotic cells [1]. These organelles are oxygen-consuming electrochemical generators, where, in the process of oxidative phosphorylation (OXPHOS), the reduction of $\mathrm{O}_{2}$ is electrochemically coupled to the conservation of energy in the form of ATP [2,3]. Mitochondria are a biochemical hub where more than 1000 biochemical reactions occur. These reactions go far beyond the oxygen-dependent production of ATP and generate metabolites, macromolecules for nucleotide and protein synthesis, and reactive oxygen species. Mitochondria also regulate a broad spectrum of biological functions including cellular chemotaxis, stress responses, cell signaling, regulation of apoptosis, and development [4,5]. Given their vital role in modulating many cellular functions, it is not surprising that mitochondrial dysfunction contributes to the pathophysiology of many diseases ranging from neurodegenerative disorders and heart failure to diabetes and cancer.

Given the important role of mitochondria, maintaining proper protein homeostasis in the organelle is critical, as is the ability to isolate and eliminate damaged mitochondria [4]. 
Mitochondrial proteostasis is mediated by specialized molecular chaperones and proteases to maintain mitochondrial protein homeostasis [6-8].

Mitochondrial proteases (i.e., mitoproteases) are the primary regulators of mitochondrial proteostasis. Initially, mitoproteases were thought to primarily function as quality control enzymes that removed damaged proteins from sub compartments of the mitochondria. Upon further study, however, additional roles for these proteases have been identified. It is now understood that mitoproteases also process mitochondrial proteins into mature and functional forms, regulate protein half-life, and, in some cases, act as scaffolds independent of their proteolytic activity [7].

Mitochondria harbor a proteome of more than 1000 proteins, containing at least 45 proteases distributed in the outer membrane (OM), intermembrane space (IMS), inner membrane (IM), or mitochondrial matrix [6,9]. These proteases are encoded in the nucleus, synthesized in the cytoplasm, and are subsequently transferred into the mitochondria through a series of import channels and carriers [5,10].

Few of the mitochondria-localized enzymes are called pseudomitoproteases, which are catalytically inactive but functionally proficient as subunits of proteolytic complexes. The remaining mitoproteases are divided into functional categories such as mitochondrial processing protease (MPP), oligopeptidases, ATP-dependent proteases, and other mitochondrial peptidases [6-9] (Table 1).

Mitochondrial processing peptidases are mostly localized to the matrix and are among the first identified mitoproteases [5,11]. Many mitochondrial precursor proteins require proteolytic removal of their mitochondrial targeting sequences (MTSs) once imported into the mitochondrial matrix. The mitochondrial processing peptidase MPP, which consists of two subunits, the proteolytic subunit PMPCB and the catalytically inactive subunit PMPCA, cleaves MTSs in the mitochondrial matrix. Protein processing is not limited to the matrix. Some proteins also require further processing for their stabilization by the mitochondrial intermediate peptidase (MIP), inner membrane protease (IMMP), or in the intermembrane space (IMS). Proteases from this family, that are involved in these processes, include the presenilin-associated rhomboid-like protease (PARL), the IM metalloendopeptidase OMA1, Met aminopeptidase 1D (METAP1D), and the X-Pro aminopeptidase 3 (XNPEP3) [4,5]. For example, upon loss of mitochondrial membrane potential, OMA1 cleaves the inner mitochondrial protein OPA1 to regulate mitochondrial dynamics [12].

Table 1. Intrinsic mitochondrial proteases, functions, and related diseases.

\begin{tabular}{|c|c|c|c|c|c|}
\hline Category & Protease & $\begin{array}{l}\text { Mitochondria } \\
\text { Localization }\end{array}$ & Function & Pathology & References \\
\hline \multirow{3}{*}{$\begin{array}{l}\text { ATP-dependent } \\
\text { proteases }\end{array}$} & $\begin{array}{l}\text { YME1L } \\
\text { (i-AAA) }\end{array}$ & IM/IMS & $\begin{array}{l}\text { Mitochondrial biogenesis } \\
\text { PQC } \\
\text { Lipid trafficking } \\
\text { Protein import }\end{array}$ & $\begin{array}{l}\text { Optic atrophy } \\
\text { Pancreatic ductal adenocarcinoma }\end{array}$ & [12-16] \\
\hline & $\begin{array}{l}\text { AFG3L2 } \\
\text { AFG3L2/SPG7 } \\
\text { (m-AAA) }\end{array}$ & Matrix/IM & $\begin{array}{l}\text { Mitochondrial biogenesis } \\
\text { PQC } \\
\text { MCU assembly }\end{array}$ & $\begin{array}{l}\text { Spinocerebellar ataxia } \\
\text { Spastic ataxia } 5\end{array}$ & {$[5,17-21]$} \\
\hline & CLPP & Matrix & $\begin{array}{l}\text { Mitochondrial biogenesis } \\
\text { PQC }\end{array}$ & $\begin{array}{l}\text { Acute myeloid leukemia } \\
\text { Prostate cancer } \\
\text { Breast cancer } \\
\text { Lung cancer } \\
\text { Liver cancer } \\
\text { Ovarian cancer } \\
\text { Bladder cancer } \\
\text { Thyroid cancer } \\
\text { Perrault syndrome } 3\end{array}$ & {$[17,22-29]$} \\
\hline
\end{tabular}


Table 1. Cont.

\begin{tabular}{|c|c|c|c|c|c|}
\hline Category & Protease & $\begin{array}{l}\text { Mitochondria } \\
\text { Localization }\end{array}$ & Function & Pathology & References \\
\hline & LONP1 & Matrix & $\begin{array}{l}\text { Mitochondrial biogenesis } \\
\text { PQC } \\
\text { Hypoxia adaptation }\end{array}$ & $\begin{array}{l}\text { Non-small-cell lung cancer } \\
\text { Cervical cancer } \\
\text { Bladder cancer } \\
\text { Colon cancer } \\
\text { Acute myeloid leukemia } \\
\text { Glioma } \\
\text { Lymphoma } \\
\text { CODAS syndrome }\end{array}$ & {$[17,23,30-41]$} \\
\hline \multirow{8}{*}{$\begin{array}{l}\text { Processing } \\
\text { peptidases }\end{array}$} & ATP23 & IMS & $\begin{array}{l}\text { processing peptidase } \\
\text { PQC } \\
\text { F1FO-ATP synthase } \\
\text { assembly }\end{array}$ & Unknown & {$[42,43]$} \\
\hline & $\begin{array}{l}\text { IMMP1L } \\
\text { IMMP2L }\end{array}$ & IM/IMS & $\begin{array}{l}\text { Protein maturation } \\
\text { Apoptosis/senescence }\end{array}$ & $\begin{array}{l}\text { Thyroid cancer } \\
\text { Gilles de la Tourette syndrome } \\
\text { Aniridia }\end{array}$ & [44-49] \\
\hline & OMA1 & IM/IMS & $\begin{array}{l}\text { Mitochondrial dynamics } \\
\text { Mitophagy and apoptosis }\end{array}$ & $\begin{array}{l}\text { Gynecological cancer } \\
\text { Breast cancer } \\
\text { Colorectal cancer }\end{array}$ & {$[12,17,50-52]$} \\
\hline & PARL & $\mathrm{IM}$ & $\begin{array}{l}\text { Mitophagy and apoptosis } \\
\text { Lipid trafficking } \\
\text { Coenzyme Q biosynthesis } \\
\text { Complex III assembly }\end{array}$ & $\begin{array}{l}\text { Parkinson disease } \\
\text { Striatal neuronal injury } \\
\text { Type } 2 \text { diabetes mellitus }\end{array}$ & [53-59] \\
\hline & METAP1D & Matrix & Protein maturation & Colon cancer & {$[5,17,60,61]$} \\
\hline & MIP & Matrix & $\begin{array}{l}\text { Coenzyme Q biosynthesis } \\
\text { Complex III and IV } \\
\text { activity } \\
\text { Protein import and } \\
\text { activation }\end{array}$ & $\begin{array}{l}\text { Left ventricular non-compaction, } \\
\text { hypotonia, and infantile death }\end{array}$ & {$[5,62-64]$} \\
\hline & РМРСВ & Matrix & Protein maturation & Cerebellar atrophy & {$[5,65,66]$} \\
\hline & XPNPEP3 & Matrix & $\begin{array}{l}\text { Protein maturation } \\
\text { Protein stability }\end{array}$ & $\begin{array}{l}\text { Nephronophthisis-like } \\
\text { nephrop-athy }\end{array}$ & {$[67,68]$} \\
\hline \multirow{2}{*}{ Oligopeptidases } & MEP & IMS & PQC & Acute myeloid leukemia & {$[5,17,69]$} \\
\hline & PITRM1 & Matrix & PQC & Amyloidotic neurodegeneration & {$[5,17,70,71]$} \\
\hline \multirow{5}{*}{ Pseudoproteases } & PARK7 & Matrix & $\begin{array}{l}\mathrm{PQC} \\
\text { Mitochondria dynamics } \\
\text { Mitophagy and apoptosis } \\
\text { Hypoxia adaption }\end{array}$ & $\begin{array}{l}\text { Parkinson disease } \\
\text { Astrocytoma } \\
\text { Breast cancer } \\
\text { Ovarian cancer } \\
\text { Prostate caner }\end{array}$ & [72-81] \\
\hline & PMPCA & Matrix & $\begin{array}{l}\text { Protein import and } \\
\text { activation }\end{array}$ & Cerebellar ataxias & {$[82,83]$} \\
\hline & UQCRC1 & IM & $\begin{array}{l}\text { Oxidative } \\
\text { phosphorylation }\end{array}$ & $\begin{array}{l}\text { Rett syndrome, } \\
\text { Obesity } \\
\text { Breast/ovarian cancer } \\
\text { Pancreatic cancer } \\
\text { Kidney cancer }\end{array}$ & [84-89] \\
\hline & UQCRC2 & IM & $\begin{array}{l}\text { Oxidative } \\
\text { phosphorylation }\end{array}$ & $\begin{array}{l}\text { Metabolic Decompensation } \\
\text { Colorectal cancer }\end{array}$ & {$[84,90-92]$} \\
\hline & PRSS35 & Unknown & Oocyte fertilization & $\begin{array}{l}\text { Nonsyndromic cleft lip and palate } \\
\text { Kidney fibrosis } \\
\text { Squamous cell carcinomas }\end{array}$ & {$[52,93-95]$} \\
\hline \multirow{2}{*}{$\begin{array}{l}\text { Other } \\
\text { mitochondrial } \\
\text { proteases }\end{array}$} & $\begin{array}{l}\text { HTRA2 } \\
\text { (OMI) }\end{array}$ & IMS & $\begin{array}{l}\text { PQC } \\
\text { Mitophagy and apoptosis } \\
\text { Stress signaling }\end{array}$ & $\begin{array}{l}\text { Ovarian serous carcinomas } \\
\text { Parkinson disease and essential } \\
\text { tremor }\end{array}$ & {$[19,96-100]$} \\
\hline & LACTB & IMS & $\begin{array}{l}\text { Mitochondrial biogenesis } \\
\text { PE metabolism }\end{array}$ & $\begin{array}{l}\text { Breast cancer } \\
\text { Colorectal cancer } \\
\text { Liver cancer }\end{array}$ & {$[17,101-104]$} \\
\hline
\end{tabular}

Abbreviations: IM, inner membrane; IMS, intermembrane space; PQC, protein quality control; $\mathrm{MCU}$, mitochondrial $\mathrm{Ca}^{2+}$ uniporter; CODAS syndrome, Cerebral, ocular, dental, auricular, and skeletal syndrome; PE, phosphatidylethanolamine. 
The ATP-dependent proteases, which are the focus of this current review, are found in all mitochondrial compartments. These multimeric, cylinder-shaped complexes, mediate the active remodeling, unfolding, and degradation of mitochondrial proteins using energy derived from ATP hydrolysis. The four known members of this class include the mitochondrial ATP-dependent protease La (Lon) localized to the mitochondrial matrix, the integral membrane proteases $\mathrm{i}-\mathrm{AAA}$, and $\mathrm{m}$-AAA proteases localized to the inner mitochondrial membrane, and the ClpXP complex in the mitochondrial matrix (ClpXP: the serine protease ClpP and the AAA+ ATPase ClpX) [5,9] (Figure 1).

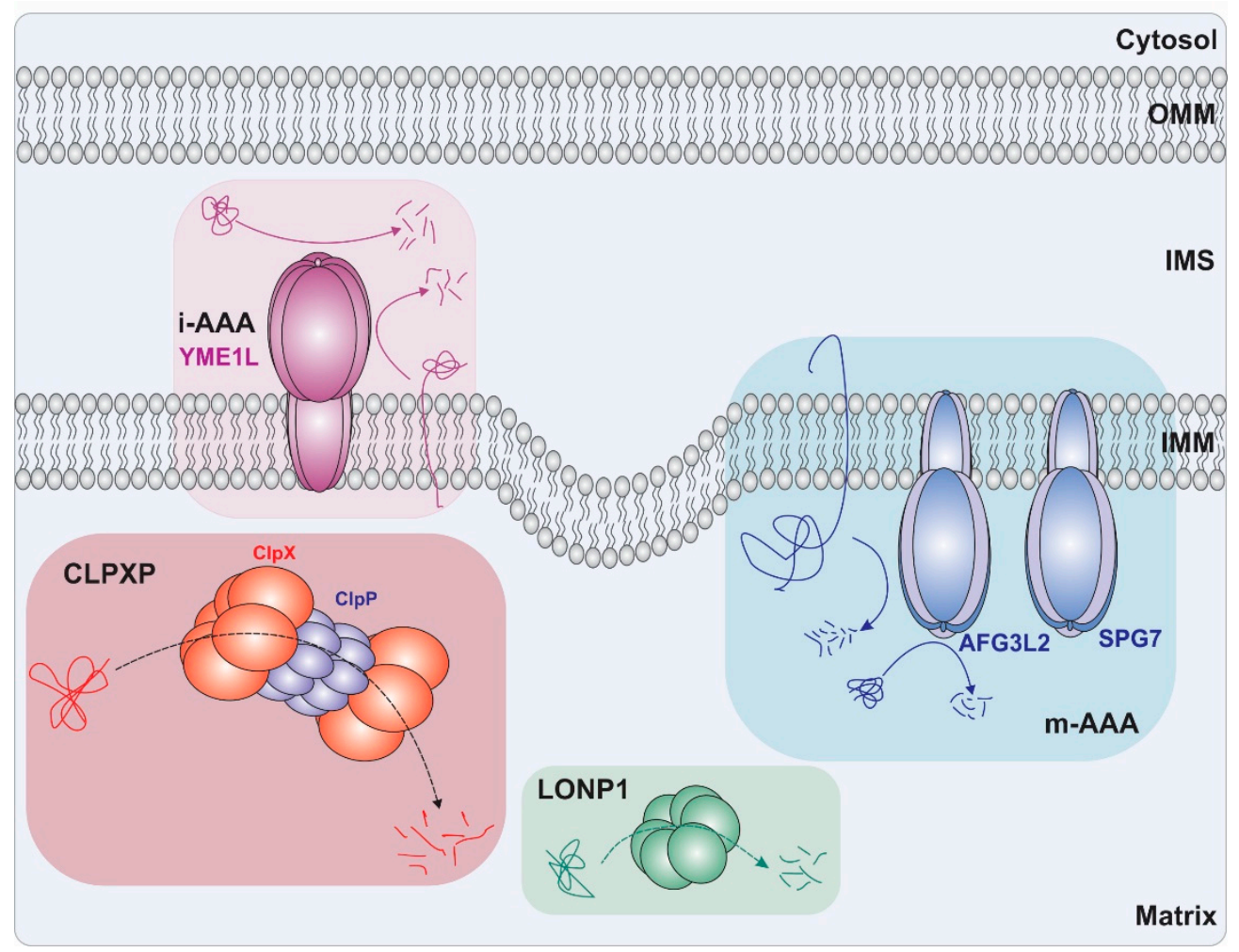

Figure 1. Schematic representation of mitochondrial ATP-dependent proteases. Mammalian mitochondria comprise four different proteases of the AAA+ superfamily for regulating protein quality control: The ClpXP complex and Lon protease 1 in the matrix and the i-AAA and m-AAA proteases in IM. Abbreviations: IMM, inner mitochondrial membrane, OMM, outer mitochondrial membrane; IMS: intermembrane space.

Oligopeptidases are present in both the matrix (e.g., PITRM1) and the IMS (e.g., MEP). They degrade the proteolytic products of ATP-dependent proteases as well as mitochondrial signaling sequences cleaved off from new imported mitochondrial proteins [5].

Lastly, other mitoproteases, such as LACTB ( $\beta$-lactamase-like protein), and HTRA2 (high temperature requirement mitochondrial serine protease A2) in intermembrane space (IMS), also act as regulators of mitochondrial lipid metabolism [104] and play a critical role in maintaining mitochondrial cristae structure [100], respectively.

In this review, we will discuss the ATP-dependent proteases with a primary focus on the ClpXP. We will discuss the biological function of ClpXP and the evidence supporting the development of ClpXP ligands for the treatment of cancer.

\section{ATP-Dependent Proteases and Their Cellular Function}

\section{1. $i-A A A$}

The i-AAA is a 733-residue integral hexameric membrane metalloprotease encoded by the nuclear YME1L1 gene and located in the inner membrane of mitochondria (IMM) $[5,105]$ with both the AAA+ ATPase and proteolytic domains facing the IMS site $[5,106]$ (Figure 1). 
i-AAA functions in the proteolytic clearance of misfolded proteins in the IMS and IMM [107]. $\mathrm{i}$-AAA recognizes degrons on the $\mathrm{N}$ - or $\mathrm{C}$-terminus of its substrates. The recognized substrate then will actively be unfolded and degraded in a processive manner by i-AAA [107] Furthermore, in response to stimuli such as increased ROS production, dissipation of mitochondrial membrane potential, heat shock, and loss of mitochondrial DNA (mtDNA), this enzyme performs central regulatory roles by complete or partial proteolysis of specific proteins, including OPA1 (optic atrophy 1), TIMM17A (translocase of inner mitochondrial membrane 17A) and ROMO1 (Reactive oxygen species modulator 1). For example, YME1L1, together with the OMA1 process, OPA1; hence, balancing mitochondrial fusion and fission [5]. In addition, under stress conditions such as changes in levels of ATP, i-AAA and the OMA1 metalloprotease participate in reciprocal proteolysis causing mitochondrial depolarization $[5,108]$. i-AAA also has a direct effect on the morphology of mitochondrial cristae and the turnover rates of NDUFB6 (NADH dehydrogenase [ubiquinone] 1 beta subcomplex subunit 6) and ND1 (NADH-ubiquinone oxidoreductase chain 1) subunits of Complex I and COX4 (Cytochrome c oxidase subunit 4) from mitochondrial Complex IV [105]. i-AAA inhibition results in the accumulation of these respiratory subunits and consequently increased oxidative stress, which leads to reduced cellular proliferation [105]. Moreover, i-AAA mediates the turnover of PRELID1 (protein of relevant evolutionary and lymphoid interest 1) [15], which facilitates the accumulation of cardiolipin in mitochondrial membranes and modulates apoptosis [14].

\section{2. $m-A A A$}

m-AAA protease is an integral membrane metalloprotease encoded by the AFG3L2 gene that preferentially localizes to the inner membrane and exposes its catalytic activity toward the matrix site [109] (Figure 1). This protease is formed by homo-oligomers of AFG3L2 (AFG3 ATPase family gene 3-like 2) or hetero-oligomers with AFG3L2 and paraplegin, a homolog of m-AAA encoded by the nuclear SPG7 gene, which is co-localized to IMM and shares the same topology [4,5]. Both m-AAA and paraplegin play a crucial role in the maintenance of aerobic respiration by regulating mitochondrial protein quality and degradation. The reduction of these proteases leads to a variety of respiratory deficiencies and causes deleterious cellular phenotypes such as Complex I deficiency and increased cellular sensitivity to oxidative stress [110]. m-AAA also implements vital functions which are essential in neuronal cells and mutations in AFG3L2 and SPG7 result in neurodegenerative phenotypes $[4,18,111,112]$. Furthermore, the m-AAA protease proteolytically processes key substrates and thereby regulates mitochondrial protein synthesis and network integrity $[113,114]$.

\subsection{Lon Protease (LonP)}

LonP1 is a 959-residue long AAA+ serine protease that resides in the mitochondrial matrix and forms homohexameric complexes (Figure 1). It is encoded by the nuclear LONP1 gene [36]. The primary function of this ATP-dependent serine protease is to maintain the mitochondrial proteome, mainly via the clearance of misfolded, unassembled, or oxidatively damaged proteins $[115,116]$. As part of the cell's adaptation to stress or changes in respiratory conditions, LonP1 also targets specific subunits of respiratory complexes for degradation. For example, LonP1 directly interacts and degrades peripheral arm subunits of complex I [117], facilitates the turnover of SDHFA2 in complex II [118], and degrades isoform 1 of the cytochrome c oxidase subunit 4 (COX4-1) [119]. LonP1 also regulates metabolic pathways such as renal glutamine catabolism [120], suppresses the transfer of cholesterol from the outer mitochondrial membrane to the inner mitochondrial membrane [121], and participates in heme biogenesis [122,123]. LonP1 is also involved in the regulation of mitochondrial DNA (mtDNA) copy numbers and mitochondrial transcription by selective downregulation of mitochondrial transcription factor A (TFAM), a DNA binding protein required for mtDNA maintenance [124,125]. 


\section{4. $C l p X P$}

$\mathrm{ClpP}$ is a 277 amino acids protease that resides in the mitochondrial matrix of a wide variety of eukaryotes, including humans. It is encoded on chromosome 19 [126]. After translation in the cytosol, it translocates to the mitochondrial matrix by a mitochondrial targeting sequence (MTS), which is cleaved upon protein maturation in the matrix $[127,128]$.

Mitochondrial $\mathrm{ClpP}$ is comprised of two identical stable heptameric rings which form a large cylindrical tetradecamer with an aqueous chamber containing 14 internal catalytic cleavage sites $[9,129]$. While bacterial $\mathrm{ClpP}$ mostly exists as a double-ring tetradecamer, mitochondrial $\mathrm{ClpP}$ exists as an inactive but stable single heptamer ring. It exists in extended, compacted, and compressed conformational states but only the extended form is catalytically active and degrades substrates [127,129-131].

Mitochondrial ClpP lacks ATPase activity and each subunit digests small peptides up to six amino acids [132]. Mitochondrial ClpP complexes with its ATPase (ClpX) to form an active protease with processive proteolytic activity to degrade full-length substrates $[113,127,129]$.

ClpX is the only known ATPase component for mammalian ClpP. It is a nuclearencoded protein and a member of ATPases associated with various cellular activities (AAA+) superfamily [129]. Similar to ClpP, ClpX also has an N-terminal mitochondrial targeting sequence (MTS). It is a hexameric ring with 6-fold symmetry and becomes stable by binding to ATP [127].

To form the ClpXP protease complex, each end of the barrel-shaped ClpP tetradecamer is capped with the ClpX hexamer [133] (Figure 1). This interaction is mediated by interactions between the flexible $\mathrm{N}$-terminal loop of $\mathrm{ClpP}$ and the pore-2 loop of $\mathrm{ClpX}$ and is stabilized by a tripeptide IGF loop on ClpX [9,133-135].

In an ATP-dependent process, $\mathrm{ClpX}$ recognizes and unfolds substrates for degradation and then feeds them into the lumen of ClpP's proteolytic chamber where they are degraded into small peptides fragments independent of ATP hydrolysis [136]. In bacteria, substrate recognition typically depends on specific linear sequence motifs named degrons $[135,137,138]$, but the substrate recognition features of mitochondrial ClpXP are unknown and need further functional characterization.

The main role of mitochondrial ClpXP is to maintain protein quality control by degrading damaged or misfolded substrates such as those involved in electron transport, metabolic processes, and the Citric acid (TCA) cycle $[24,26,128,139]$. Beyond its role in mitochondrial protein degradation, $\mathrm{ClpX}$ also plays a critical role in regulating heme biosynthesis [140], mtDNA nucleoid distribution [141], and promoting apoptosis [141]. Studies in Caenorhabditis elegans also demonstrate that ClpXP regulates the mitochondrial unfolded protein response (UPRmt). In Caenorhabditis elegans, small peptides generated by ClpXP-mediated protein degradation upon mitochondrial stress are exported out of the mitochondria into the cytoplasm by the HAF-1 transporter and initiates the mtUPR response in the nucleus $[1,142,143]$. While ClpXP is an important regulator of mtUPR in the worm, additional studies are needed to clarify the role of this protease in mtUPR in mammalian cells as ClpP inhibition in AML did not alter the expression of mtUPR proteins [24].

\section{ATP-Dependent Proteases and Cancer}

ATP-dependent proteases (AAA+ proteases) play critical roles in the clearance of misfolded or damaged proteins from the mitochondria. Given that changes in cellular metabolism and bioenergetics, oxidative stress, and intracellular ROS level are hallmarks of cancer development, these proteases are also important for the proliferation and metastasis of certain cancers. Therefore, targeting AAA+ proteases might have efficacy against malignancy. 


\section{1. $i-A A A, m-A A A$ and LonP}

The link between i-AAA and m-AAA and cancer is not well established or available data are limited. However, LonP1 is expressed at high levels in specific cancers such as cervical, lung, bladder, colon cancer, and acute myeloid leukemia [36-41].

Several studies report the effect of LonP1 knockdown in human cell lines. For example, LonP1 knockdown in human lung fibroblasts and bladder cancer cells causes caspase-3dependent cell death and suppresses cell proliferation [144,145]. LonP1 knockdown also reduces cell proliferation in human mantle cell lymphoma and non-small-cell lung cancer (NSCLC) cell lines $[34,35]$. Similarly, siRNA knockdown of LonP1 reduces the viability of human malignant glioma cells and radically impairs glioma cell survival under hypoxic conditions [32]. Conversely, LonP1 overexpression promotes cancer cell proliferation, enhances colony formation, and more importantly, increases cellular resistance to apoptosisinducing reagents $[38,146]$. Therefore, its inhibition using specific chemical inhibitors has been explored as a potential therapeutic strategy.

For example, triterpenoids such as oleanane 2-cyano-3,12-dioxooleana-1,9-dien-28-oic acid (CDDO), also known as Bardoxolone (RTA-401), and its derivatives such as CDDO-Me inhibit the proteolytic activity of LonP1 [34]. CDDO, in the micromolar range, induces caspase-dependent apoptosis in several human cancer cells with high LonP1 expression, comprising colon carcinoma, B-cell lymphoma, breast ductal carcinoma, and liver hepatocellular carcinoma [34,146]. Phase I clinical trials on CDDO in solid tumors [147] and acute myeloid leukemia [148] have also been conducted but, to date, have failed to confirm the anti-cancer effects in patients.

In addition to CDDO and its derivatives, new classes of LonP1 inhibitors such as $\gamma$-lactone Obtusilactone A (OA) have also been discovered and characterized [149]. Further studies show that this natural product inhibits the proteolytic activity of LonP1 both in vitro and in vivo [35]. (-)-Sesamin is another natural product isolated from Cinnamomum kotoense that also inhibits LonP1 and induces apoptosis in NSCLC cells [35]. However, the likely toxicity of these inhibitors has limited the interest in developing such compounds.

Inactivating mutations in other mitochondrial proteases leads to developmental, metabolic, and neurological disorders such as CODAS syndrome (CODASS), Perrault syndrome 3 (PRLTS3), optic atrophy 11 (OPA11), erythropoietic protoporphyria (EPP), spinocerebellar ataxia 28 (SCA28), and hereditary spastic paraplegia 7 (HSP7) [20,28,150,151]. Likewise, Lon is essential for survival in mammals, and homozygous deletion of LONP causes early embryonic lethality [152]. Thus, the potential toxicity of inhibiting these proteases as anti-cancer therapies could be high.

\subsection{ClpXP and Cancer}

In contrast to the proteases mentioned above, targeting ClpXP may eliminate malignant cells while sparing normal tissues. In support of this hypothesis, $\mathrm{ClpP}$-/- mice are viable, however, slightly smaller, infertile, and have acquired hearing loss [132]. In humans, there are rare individuals from consanguineous families with homozygous inactivating mutations in ClpP. These individuals are viable but also have acquired hearing loss and infertility $[28,153]$. Therefore, inhibiting ClpXP may have a therapeutic window in the treatment of malignancy, and we focus the remainder of this review on ClpXP as a potential therapeutic target for cancer therapy.

Emerging evidence suggests that alterations in metabolism and bioenergetics are hallmarks of cancer $[154,155]$. For a subset of patients, including some with acute myeloid leukemia (AML), chronic myeloid leukemia (CML), pancreatic ductal adenocarcinoma (PDAC), and breast cancer [24,156-161], have increased reliance on respiratory function due to limited spare reserve capacity [158], increased TCA cycle substrates [159,162] and low metabolic-plasticity upon OXPHOS inhibition [156,162,163]. In addition, optimal biogenesis and OXPHOS function are crucial for metastatic dissemination as shown with PGC-1 $\alpha$ (peroxisome proliferator-activated receptor gamma coactivator 1-alpha) silencing 
in the breast cancer model [164]. These data highlight the therapeutic potential of targeting OXPHOS function and regulation of ROS production.

Consistent with the essential roles of ClpXP in maintaining OXPHOS function, expression of ClpP has also increased in acute myeloid leukemia [24], as well as some patients with solid tumors such as breast, lung, liver, ovary, bladder, prostate, uterus, stomach, prostate, testis, thyroid and non-small cell lung cancer (NSCLC) [26,27,29]. In addition, increased $\mathrm{ClpP}$ expression is correlated with poor prognosis and lower metastasis-free survival in patients with breast adenocarcinoma, uveal melanoma, and lung adenocarcinoma [26].

\subsubsection{ClpXP and AML}

Studies support targeting ClpXP for a subset of AML patients. Compared to normal CD34+ hematopoietic cells, $45 \%$ of AML patients have increased ClpP expression. Increased $\mathrm{ClpP}$ is seen across genetic and molecular subtypes but correlates with increased mitochondrial stress. Genetic and chemical inhibition of ClpP reduces leukemia cell growth and viability and targets leukemic stem cells in vitro and in vivo (Figure 2). Inhibiting ClpP preferentially targets AML cells and primary samples with the highest levels of ClpP while sparing normal hematopoietic cells [24].

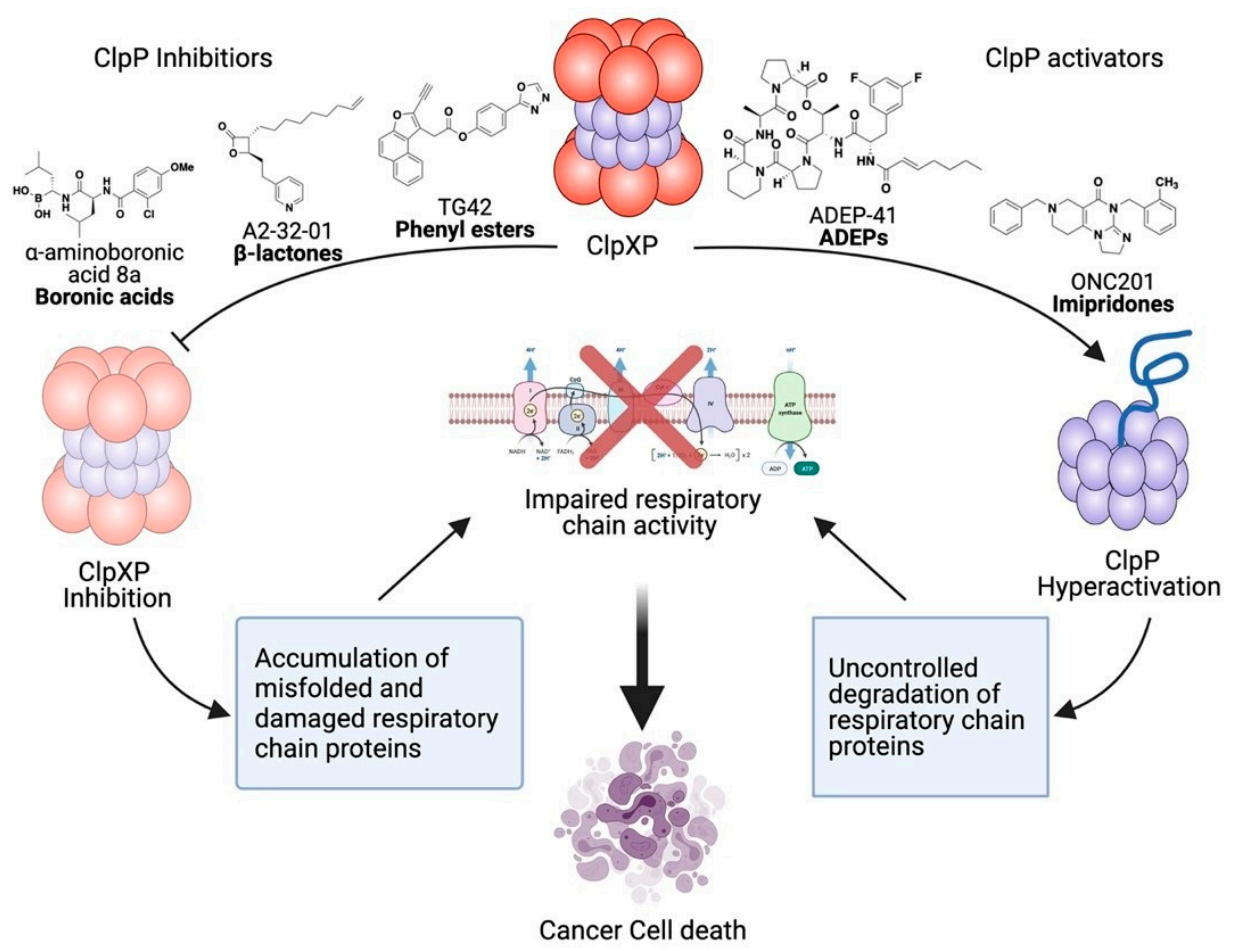

Figure 2. ClpXP inhibition and hyperactivation lead to cancer cell death. Genetic and chemical inhibition of ClpXP leads to the accumulation of misfolded and damaged respiratory chain proteins and impairs oxidative phosphorylation which results in selective cancer cell death. ClpP chemical activators and mutated hyperactive $\mathrm{ClpP}$ result in uncontrolled degradation of $\mathrm{ClpP}$ substrates. ClpP hyperactivation causes mitochondrial morphological damage and decreased oxidative phosphorylation, which also results in cancer cell death.

Interestingly, hyperactivation of $\mathrm{ClpP}$ also effectively targets AML cells by uncontrolled degradation of OXPHOS subunits [25]. Induction of constitutively active ClpP mutant (Y118A) and hyperactivation by imipridones increases degradation of respiratory chain proteins and metabolic enzymes resulting in impaired respiratory function. The small molecule imipridone binds ClpP outside of the active site and produces conformational changes in the enzyme complex resulting in the opening of the axial proteolytic pore and compaction of the protease. Similar changes are produced by the genetic mutant. These changes lead to hyperactivation of $\mathrm{ClpP}$ and increase substrate degradation in a 
selective, but uncontrolled manner. ClpP hyperactivation induces apoptosis in leukemia and lymphoma cells preferentially over normal cells [25]. Thus, these studies support the development of both ClpP inhibitors and activators as novel therapies for malignancy (Figure 2). To date, it is unknown whether inhibiting or activating ClpP is the preferred therapeutic strategy.

\subsubsection{ClpXP and Prostate Cancer}

ClpXP has also been identified as a novel survivin-associated protein in a proteomic screen using the prostate adenocarcinoma cell line, PC3 [26]. siRNA silencing of ClpP or $\mathrm{ClpX}$ in $\mathrm{PC} 3$ cells significantly suppresses proliferation and colony formation by decreasing the expression of cyclins A, B1, and D1 and inducing cell cycle arrest. ClpXP is also involved in tumor metastasis and cell migration [26]. PC3 cells with repressed ClpP expression xenografted into immunocompromised mice show decrease invasion and metastasis [26].

\subsubsection{ClpXP and Breast Cancer}

According to The Cancer Genome Atlas (TCGA) database, ClpP is highly expressed in breast cancer tissue and is correlated with the T stage, ER expression, and lower recurrencefree survival [27]. In addition, loss of $\mathrm{ClpP}$ suppresses cell growth, migration, and colony formation in the breast cancer cell lines MDA-MB-231 and ZR-75-1 [27]. In contrast, in the breast adenocarcinoma cell line MCF-7, ClpP is highly expressed but the loss of ClpP had minimal effects on cell proliferation which suggests the importance of ClpP expression in cancer pathology may be cell-type specific [26].

\section{Therapeutic Development of ClpXP Ligands as Anti-Cancer Agents}

\subsection{ClpXP Inhibitors}

\subsubsection{B-Lactones}

In 2008, through activity-based protein profiling, trans-ß-lactones were identified that inhibit $\mathrm{ClpP}$ by covalently blocking the active site. These compounds have antibacterial effects against Staphylococcus aureus (S. aureus) [165]. The hydrophobic R1 chain of Blactones bind adjacent to the $\mathrm{ClpP}$ active site [166] and facilitate its electrophilic core scaffold attacking the catalytic Ser [167]. A synthetic B-lactone A2-32-01 inhibits recombinant human ClpXP enzyme [24]. In cell culture models, A2-32-01 inhibits AML cell viability and reduces clonogenic growth [24] (Figure 2). In vivo, daily treatment of A2-32-01 reduces leukemic growth without liver, muscle, or renal toxicity [24]. The cyclic ester of ß-lactones is quickly hydrolyzed in human plasma. For example, more than $90 \%$ of A2-32-01 is hydrolyzed in

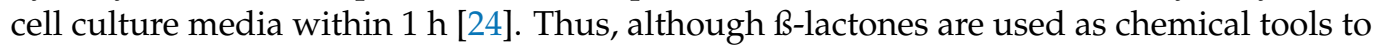
study ClpP inhibition, they are not candidates for clinical development due to their poor selectivity and stability.

\subsubsection{Phenyl Esters}

Phenyl esters were found through an unbiased high throughput screen of more than 137,000 compounds for their ability to inhibit S. aureus ClpP (SaClpP) peptidase activity. Like B-lactones, phenyl esters also covalently bind to the ClpP catalytic Ser and trap ClpP in the acyl-enzyme intermediate state, which causes deoligomerization of $\mathrm{ClpP}$ [168]. Compared to ß-lactones, phenyl ester $\mathrm{ClpP}$ inhibitors have improved potency and stability [168]. However, only the AV167 inhibits human ClpP peptidase activity [168].

To improve selectivity for human ClpP, the modified analogues TG42, TG43, and TG53 were generated by substituting a naphtofuran moiety at position-2 [169]. The TG compounds inhibit both hClpP peptidolyic and proteolytic activities [169]. TG42 and TG53 induce apoptosis and inhibit cell migration in Huh7 cancer cells [169] (Figure 2). However, activity-based protein profiling (ABPP) experiments suggest that TG42 interacts with multiple human proteins other than hClpP [169]. Therefore, the mechanism by which TG42 and related compounds induce cell death is uncertain and may be due to effects 
on targets beyond ClpP. The off and on-target effects of these compounds remain to be elucidated before they can proceed to clinical application.

\subsubsection{Boron-Containing Molecules}

Boron-containing molecules (BCMs) are another class of compounds that targeting both human and bacterial ClpP. Both C-terminal boronic acids $8 \mathrm{a}-\mathrm{c}(\alpha$-amino boronic acids) and N-terminal boronic acids WLS6a inhibit ClpXP enzyme activity in cell-free assays $[170,171]$ (Figure 2). Crystal structure of compound-bound SaClpP and virtual modeling of human ClpP suggest the $\alpha$-amino boronic acids interact with the catalytic serine residue [171]. Although promising leads for the development of ClpP inhibitors, the stability, potency, and selectivity of these compounds need to be validated and their efficacy in vitro and in vivo needs to be determined.

\subsection{ClpXP Activators}

\subsubsection{ADEPs}

ADEPs are small molecule ClpP activators that were first isolated from Streptomyces hawaiiensis fermentation broth [172]. ADEPs typically contain a lactone core, a phenylalanine linker region, and a hydrophobic tail [173]. These compounds bind ClpP outside of the active site and interrupt the docking of the ClpX IGF loop to ClpP. As a result, these compounds displace ClpX from ClpP. Upon binding to ClpP, these compounds enlarge the ClpP pore leading to selective but uncontrolled proteolysis $[173,174]$ (Figure 2). Originally, ADEPs were discovered as bacterial $\mathrm{ClpP}$ activators that inhibit bacterial cell division and kill bacteria by uncontrolled proteolysis [175]. A later study demonstrated that the compounds cross reacts with human ClpP [176]. ADEP-41 kills cancer cell lines including HeLa, U2OS, and undifferentiated SH-SY5Y cell lines [176]. The cytotoxic effects of ADEP are mediated through mitochondrial fragmentation and abolishing OXPHOS function [176].

\subsubsection{Imipridones}

ONC201, the founding member of imipridones, is in clinical trials for multiple advanced cancers, including hematological malignancies and solid tumors including breast cancer and glioblastoma. Recent studies suggest that other than targeting the bulk cancer cells, imipridones also target cancer stem cells and cancer-associated fibroblasts, as well as activate immune cells in the tumor microenvironment [177,178].

Weekly ONC201 is well tolerated in recurrent glioblastoma patients [179,180]. Early studies suggest that single-agent treatment with ONC201 may prolong survival in a subset of these patients [179]. In addition, combination therapy has also been explored. The addition of exogenous TRAIL receptor agonists prime ONC201 to exert an apoptotic effect in a death receptor (DR5)-dependent manner for non-triple negative breast cancer (TNBC) cells [181]. Also, 2-Deoxyglucose and imipridones result in dual metabolic reprogramming that synergistically depletes energy in glioblastoma [182].

As for the mechanism of action, imipridones, including ONC201, ONC212, and TR compounds were identified as ClpP activators [25,183,184]. Like ADEPs, ONC201 non-covalently binds to the hydrophobic pocket between ClpP subunits and opens the axial entrance [25]. ONC201 treatment abolishes respiratory chain complexes I, II, and IV activity and induces morphological damage of matrix and cristae structure $[25,183]$ (Figure 2). AML, acute lymphoblastic leukemia (ALL) and breast cancer cells with inactive mutant ClpP (D190A) or ClpP knockout are resistant to ONC201 and ONC212, indicating the functional importance of $\mathrm{ClpP}$ for imipridones efficacy. Downstream of $\mathrm{ClpP}$ activation, imipridones induce the integrated stress response (ISR) and subsequently upregulate the ATF4/CHOP (activating transcription factor 4/CCAAT enhancer-binding protein homologous protein) $[25,185]$.

Nevertheless, ClpP may not be the only target of imipridones. They are also predicted to be dopamine D2 receptor (DRD2) and dopamine D3 receptor (DRD3) antagonists by a machine learning algorithm [186]. Although DRD2 knockout does not abrogate the 
anti-cancer effect of imipridones, enhanced DRD2/DRD5 heterodimerization was inversely correlated with tumor cell sensitivity to ONC201 $[187,188]$. Transient DRD2 knockdown also activates the integrated stress response [188].

Therefore, the connection between ONC-induced ClpP activation and dopamine receptor antagonism needs to be determined. In addition, it is unknown which of the downstream molecular effects of ONC201 are related to ClpP activation versus other targets. Finally, how ClpP function and dopamine receptor signaling are involved in ONC resistance is another important field for investigation.

\section{Conclusions}

Given the function of regulating mitochondrial protein quality, ATP-dependent proteases are essential for normal mitochondrial morphology and function. Aberrant activities of ATP-dependent proteases are associated with pathologies ranging from neurodegenerative diseases to cancer $[20,32,33,54]$. Particularly, emerging studies suggest that LonP1 and ClpXP are needed to alleviate mitochondria stress and promote cancer cell survival and metastasis in a subset of solid and hematology malignancies [24,25,32,34].

Of all the mitochondrial proteases, ClpXP is unique in that humans, animals, and cells remain viable with mild phenotypes despite depletion or mutation of this protease. Coupled with the reported anti-cancer effects of targeting ClpXP, there is a promising therapeutic window to develop clinical-grade ClpXP regulators.

Currently, several classes of inhibitors and activators have been developed to target human ClpP. Mostly, the inhibitors covalently bind to the catalytic serine in ClpP and block $\mathrm{ClpP}$ proteolysis activity. In contrast, activators usually allosterically replace $\mathrm{ClpX}$ at the ClpP hydrophobic pockets and keep ClpP in the active states for selective but uncontrolled proteolysis. However, the stability, selectivity, and the ability to cross cellular and mitochondrial double membranes remain to be the major obstacles for these molecules to proceed as therapeutic compounds. To date, most efforts have focused on inhibiting ClpP. Fewer studies have focused on developing ClpX targeting molecules. Further studies assessing the efficacy and toxicity of $\mathrm{ClpX}$ inhibition in vivo and in vitro are important to evaluate the potential of targeting the ClpX regulatory subunit.

Moreover, considering the overlapping function of ATP-dependent proteases, it is important to understand mechanisms of resistance to ClpXP inhibition and hyperactivation. Moreover, since recent studies suggest $\mathrm{ClpXP}$ and LonP1 synergistically regulate cancer cell survival [189], preclinical and clinical studies on combination therapy of ClpXP regulators and other mitoproteases regulators may provide even broader applications of $\mathrm{ClpXP}$ regulators in newly-diagnosed and relapsed cancers. Finally, more biological studies are needed to determine the mechanism of action of this protease. For example, while ClpP substrates have been identified, it remains unknown what marks proteins for degradation by this enzyme. These biological studies will provide new insights into mitochondrial biology and help develop ClpXP ligands as novel therapies for subsets of patients with cancer.

Funding: This work was supported by the Canadian Institutes of Health Research, the Ontario Institute for Cancer Research with funding provided by the Ontario Ministry of Research and Innovation, the Princess Margaret Cancer Centre Foundation, and the Ministry of Long Term Health and Planning in the Province of Ontario. ADS holds the Ronald N. Buick Chair in Oncology Research.

Acknowledgments: The authors thank Jill Flewelling (Princess Margaret Cancer Centre) for administrative assistance.

Conflicts of Interest: A.D.S. has received research funding from Takeda Pharmaceuticals and Medivir $\mathrm{AB}$, and consulting fees/honorarium from Takeda, Novartis, Jazz, and Otsuka Pharmaceuticals. A.D.S. is an inventor on patent applications claiming the use of DNTs for the treatment of AML. 


\section{References}

1. Munch, C.; Harper, J.W. Mitochondrial unfolded protein response controls matrix pre-RNA processing and translation. Nature 2016, 534, 710-713. [CrossRef] [PubMed]

2. Picard, M.; Wallace, D.C.; Burelle, Y. The rise of mitochondria in medicine. Mitochondrion 2016, 30, 105-116. [CrossRef] [PubMed]

3. Tiosano, D.; Mears, J.A.; Buchner, D.A. Mitochondrial Dysfunction in Primary Ovarian Insufficiency. Endocrinology 2019, 160, 2353-2366. [CrossRef] [PubMed]

4. Gomez-Fabra Gala, M.; Vögtle, F.N. Mitochondrial proteases in human diseases. FEBS Lett. 2021. [CrossRef]

5. Deshwal, S.; Fiedler, K.U.; Langer, T. Mitochondrial Proteases: Multifaceted Regulators of Mitochondrial Plasticity. Annu. Rev. Biochem. 2020, 89, 501-528. [CrossRef]

6. Voos, W.; Jaworek, W.; Wilkening, A.; Bruderek, M. Protein quality control at the mitochondrion. Essays Biochem. 2016, 60, 213-225. [CrossRef]

7. Pfanner, N.; Warscheid, B.; Wiedemann, N. Mitochondrial proteins: From biogenesis to functional networks. Nat. Rev. Mol. Cell Biol. 2019, 20, 267-284. [CrossRef]

8. Kotiadis, V.N.; Duchen, M.R.; Osellame, L.D. Mitochondrial quality control and communications with the nucleus are important in maintaining mitochondrial function and cell health. Biochim. Biophys. Acta 2014, 1840, 1254-1265. [CrossRef]

9. Nouri, K.; Feng, Y.; Schimmer, A.D. Mitochondrial ClpP serine protease-biological function and emerging target for cancer therapy. Cell Death Dis 2020, 11, 841. [CrossRef]

10. Glynn, S.E. Multifunctional Mitochondrial AAA Proteases. Front. Mol. Biosci. 2017, 4, 34. [CrossRef]

11. Quiros, P.M.; Mottis, A.; Auwerx, J. Mitonuclear communication in homeostasis and stress. Nat. Rev. Mol. Cell Biol. 2016, 17, 213-226. [CrossRef]

12. Anand, R.; Wai, T.; Baker, M.J.; Kladt, N.; Schauss, A.C.; Rugarli, E.; Langer, T. The i-AAA protease YME1L and OMA1 cleave OPA1 to balance mitochondrial fusion and fission. J. Cell Biol. 2014, 204, 919-929. [CrossRef]

13. Richter, F.; Dennerlein, S.; Nikolov, M.; Jans, D.C.; Naumenko, N.; Aich, A.; MacVicar, T.; Linden, A.; Jakobs, S.; Urlaub, H.; et al. ROMO1 is a constituent of the human presequence translocase required for YME1L protease import. J. Cell Biol. 2019, 218, 598-614. [CrossRef]

14. Potting, C.; Tatsuta, T.; König, T.; Haag, M.; Wai, T.; Aaltonen, M.J.; Langer, T. TRIAP1/PRELI Complexes Prevent Apoptosis by Mediating Intramitochondrial Transport of Phosphatidic Acid. Cell Metab. 2013, 18, 287-295. [CrossRef]

15. Hartmann, B.; Wai, T.; Hu, H.; Macvicar, T.; Musante, L.; Fischer-Zirnsak, B.; Stenzel, W.; Gräf, R.; Van Den Heuvel, L.; Ropers, H.-H.; et al. Homozygous YME1L1 mutation causes mitochondriopathy with optic atrophy and mitochondrial network fragmentation. eLife 2016, 5, e16078. [CrossRef]

16. Macvicar, T.; Ohba, Y.; Nolte, H.; Mayer, F.C.; Tatsuta, T.; Sprenger, H.-G.; Lindner, B.; Zhao, Y.; Li, J.; Bruns, C.; et al. Lipid signalling drives proteolytic rewiring of mitochondria by YME1L. Nature 2019, 575, 361-365. [CrossRef]

17. Quiros, P.M.; Langer, T.; Lopez-Otin, C. New roles for mitochondrial proteases in health, ageing and disease. Nat. Rev. Mol. Cell Biol. 2015, 16, 345-359. [CrossRef]

18. Kondadi, A.K.; Wang, S.; Montagner, S.; Kladt, N.; Korwitz, A.; Martinelli, P.; Herholz, D.; Baker, M.J.; Schauss, A.C.; Langer, T.; et al. Loss of the m-AAA protease subunit AFG(3)L(2) causes mitochondrial transport defects and tau hyperphosphorylation. EMBO J. 2014, 33, 1011-1026. [CrossRef]

19. He, Y.C.; Huang, P.; Li, Q.Q.; Sun, Q.; Li, D.H.; Wang, T.; Shen, J.Y.; Du, J.J.; Cui, S.S.; Gao, C.; et al. Mutation Analysis of HTRA2 Gene in Chinese Familial Essential Tremor and Familial Parkinson's Disease. Parkinsons Dis. 2017, 2017, 3217474. [CrossRef]

20. Pierson, T.M.; Adams, D.; Bonn, F.; Martinelli, P.; Cherukuri, P.F.; Teer, J.K.; Hansen, N.F.; Cruz, P.; James C. Mullikin for the NISC Comparative Sequencing Program; Blakesley, R.W.; et al. Whole-exome sequencing identifies homozygous AFG3L2 mutations in a spastic ataxia-neuropathy syndrome linked to mitochondrial m-AAA proteases. PLoS Genet 2011, 7, e1002325. [CrossRef]

21. Di Bella, D.; Lazzaro, F.; Brusco, A.; Plumari, M.; Battaglia, G.; Pastore, A.; Finardi, A.; Cagnoli, C.; Tempia, F.; Frontali, M.; et al. Mutations in the mitochondrial protease gene AFG3L2 cause dominant hereditary ataxia SCA28. Nat. Genet. 2010, 42, 313-321. [CrossRef] [PubMed]

22. Matsushima, Y.; Hirofuji, Y.; Aihara, M.; Yue, S.; Uchiumi, T.; Kaguni, L.S.; Kang, D. Drosophila protease ClpXP specifically degrades DmLRPPRC1 controlling mitochondrial mRNA and translation. Sci. Rep. 2017, 7, 8315. [CrossRef]

23. Szczepanowska, K.; Maiti, P.; Kukat, A.; Hofsetz, E.; Nolte, H.; Senft, K.; Becker, C.; Ruzzenente, B.; Hornig-Do, H.T.; Wibom, R.; et al. CLPP coordinates mitoribosomal assembly through the regulation of ERAL1 levels. EMBO J. 2016, 35, 2566-2583. [CrossRef]

24. Cole, A.; Wang, Z.; Coyaud, E.; Voisin, V.; Gronda, M.; Jitkova, Y.; Mattson, R.; Hurren, R.; Babovic, S.; Maclean, N.; et al. Inhibition of the Mitochondrial Protease ClpP as a Therapeutic Strategy for Human Acute Myeloid Leukemia. Cancer Cell 2015, 27, 864-876. [CrossRef]

25. Ishizawa, J.; Zarabi, S.F.; Davis, R.E.; Halgas, O.; Nii, T.; Jitkova, Y.; Zhao, R.; St-Germain, J.; Heese, L.E.; Egan, G.; et al. Mitochondrial ClpP-Mediated Proteolysis Induces Selective Cancer Cell Lethality. Cancer Cell 2019, 35, 721-737.e729. [CrossRef]

26. Seo, J.H.; Rivadeneira, D.B.; Caino, M.C.; Chae, Y.C.; Speicher, D.W.; Tang, H.Y.; Vaira, V.; Bosari, S.; Palleschi, A.; Rampini, P.; et al. The Mitochondrial Unfoldase-Peptidase Complex ClpXP Controls Bioenergetics Stress and Metastasis. PLoS Biol. 2016, 14, e1002507. [CrossRef]

27. Luo, J.; Zeng, B.; Tao, C.; Lu, M.; Ren, G. ClpP regulates breast cancer cell proliferation, invasion and apoptosis by modulating the Src/PI3K/Akt signaling pathway. PeerJ 2020, 8, e8754. [CrossRef] 
28. Jenkinson, E.M.; Rehman, A.U.; Walsh, T.; Clayton-Smith, J.; Lee, K.; Morell, R.J.; Drummond, M.C.; Khan, S.N.; Naeem, M.A.; Rauf, B.; et al. Perrault syndrome is caused by recessive mutations in CLPP, encoding a mitochondrial ATP-dependent chambered protease. Am. J. Hum. Genet. 2013, 92, 605-613. [CrossRef] [PubMed]

29. Cormio, A.; Musicco, C.; Gasparre, G.; Cormio, G.; Pesce, V.; Sardanelli, A.M.; Gadaleta, M.N. Increase in proteins involved in mitochondrial fission, mitophagy, proteolysis and antioxidant response in type I endometrial cancer as an adaptive response to respiratory complex I deficiency. Biochem. Biophys. Res. Commun. 2017, 491, 85-90. [CrossRef] [PubMed]

30. Hao, Y.H.; Zhang, J.; Wang, H.; Wang, H.Y.; Dong, J.; Xu, X.P.; Yao, B.W.; Wang, L.F.; Zhou, H.M.; Zhao, L.; et al. HIF-1alpha regulates COXIV subunits, a potential mechanism of self-protective response to microwave induced mitochondrial damages in neurons. Sci. Rep. 2018, 8, 10403. [CrossRef]

31. Kunova, N.; Ondrovicova, G.; Bauer, J.A.; Bellova, J.; Ambro, L.; Martinakova, L.; Kotrasova, V.; Kutejova, E.; Pevala, V. The role of Lon-mediated proteolysis in the dynamics of mitochondrial nucleic acid-protein complexes. Sci. Rep. 2017, 7, 631. [CrossRef]

32. Di, K.; Lomeli, N.; Wood, S.D.; Vanderwal, C.D.; Bota, D.A. Mitochondrial Lon is over-expressed in high-grade gliomas, and mediates hypoxic adaptation: Potential role of Lon as a therapeutic target in glioma. Oncotarget 2016, 7, 77457-77467. [CrossRef]

33. Strauss, K.A.; Jinks, R.N.; Puffenberger, E.G.; Venkatesh, S.; Singh, K.; Cheng, I.; Mikita, N.; Thilagavathi, J.; Lee, J.; Sarafianos, S.; et al. CODAS Syndrome Is Associated with Mutations of LONP1, Encoding Mitochondrial AAA+ Lon Protease. Am. J. Hum. Genet. 2015, 96, 121-135. [CrossRef]

34. Bernstein, S.H.; Venkatesh, S.; Li, M.; Lee, J.; Lu, B.; Hilchey, S.P.; Morse, K.M.; Metcalfe, H.M.; Skalska, J.; Andreeff, M.; et al. The mitochondrial ATP-dependent Lon protease: A novel target in lymphoma death mediated by the synthetic triterpenoid CDDO and its derivatives. Blood 2012, 119, 3321-3329. [CrossRef]

35. Wang, H.M.; Cheng, K.C.; Lin, C.J.; Hsu, S.W.; Fang, W.C.; Hsu, T.F.; Chiu, C.C.; Chang, H.W.; Hsu, C.H.; Lee, A.Y. Obtusilactone $\mathrm{A}$ and (-)-sesamin induce apoptosis in human lung cancer cells by inhibiting mitochondrial Lon protease and activating DNA damage checkpoints. Cancer Sci. 2010, 101, 2612-2620. [CrossRef]

36. Quiros, P.M.; Espanol, Y.; Acin-Perez, R.; Rodriguez, F.; Barcena, C.; Watanabe, K.; Calvo, E.; Loureiro, M.; Fernandez-Garcia, M.S.; Fueyo, A.; et al. ATP-dependent Lon protease controls tumor bioenergetics by reprogramming mitochondrial activity. Cell Rep. 2014, 8, 542-556. [CrossRef]

37. Pinti, M.; Gibellini, L.; Liu, Y.; Xu, S.; Lu, B.; Cossarizza, A. Mitochondrial Lon protease at the crossroads of oxidative stress, ageing and cancer. Cell. Mol. Life Sci. 2015, 72, 4807-4824. [CrossRef]

38. Cheng, C.W.; Kuo, C.Y.; Fan, C.C.; Fang, W.C.; Jiang, S.S.; Lo, Y.K.; Wang, T.Y.; Kao, M.C.; Lee, A.Y. Overexpression of Lon contributes to survival and aggressive phenotype of cancer cells through mitochondrial complex I-mediated generation of reactive oxygen species. Cell Death Dis. 2013, 4, e681. [CrossRef]

39. Bota, D.A.; Davies, K.J. Mitochondrial Lon protease in human disease and aging: Including an etiologic classification of Lon-related diseases and disorders. Free Radic. Biol. Med. 2016, 100, 188-198. [CrossRef]

40. Nie, X.; Li, M.; Lu, B.; Zhang, Y.; Lan, L.; Chen, L.; Lu, J. Down-regulating overexpressed human Lon in cervical cancer suppresses cell proliferation and bioenergetics. PLoS ONE 2013, 8, e081084. [CrossRef]

41. Gibellini, L.; Pinti, M.; Boraldi, F.; Giorgio, V.; Bernardi, P.; Bartolomeo, R.; Nasi, M.; De Biasi, S.; Missiroli, S.; Carnevale, G.; et al. Silencing of mitochondrial Lon protease deeply impairs mitochondrial proteome and function in colon cancer cells. FASEB J. 2014, 28, 5122-5135. [CrossRef] [PubMed]

42. Zeng, X.; Neupert, W.; Tzagoloff, A. The metalloprotease encoded by ATP23 has a dual function in processing and assembly of subunit 6 of mitochondrial ATPase. Mol. Biol. Cell 2007, 18, 617-626. [CrossRef] [PubMed]

43. Osman, C.; Wilmes, C.; Tatsuta, T.; Langer, T. Prohibitins interact genetically with Atp23, a novel processing peptidase and chaperone for the F1Fo-ATP synthase. Mol. Biol. Cell 2007, 18, 627-635. [CrossRef] [PubMed]

44. Ieva, R.; Heisswolf, A.K.; Gebert, M.; Vogtle, F.N.; Wollweber, F.; Mehnert, C.S.; Oeljeklaus, S.; Warscheid, B.; Meisinger, C.; van der Laan, M.; et al. Mitochondrial inner membrane protease promotes assembly of presequence translocase by removing a carboxy-terminal targeting sequence. Nat. Commun. 2013, 4, 2853. [CrossRef]

45. Yuan, L.; Zhai, L.; Qian, L.; Huang, D.; Ding, Y.; Xiang, H.; Liu, X.; Thompson, J.W.; Liu, J.; He, Y.H.; et al. Switching off IMMP2L signaling drives senescence via simultaneous metabolic alteration and blockage of cell death. Cell Res. 2018, 28, 625-643. [CrossRef]

46. Bjerregaard, V.A.; Schönewolf-Greulich, B.; Juel Rasmussen, L.; Desler, C.; Tümer, Z. Mitochondrial Function in Gilles de la Tourette Syndrome Patients With and Without Intragenic IMMP2L Deletions. Front. Neurol. 2020, 11. [CrossRef]

47. Wawrocka, A.; Krawczynski, M.R. The genetics of aniridia-simple things become complicated. J. Appl. Genet. 2018, 59, 151-159. [CrossRef]

48. Bertelsen, B.; Melchior, L.; Jensen, L.R.; Groth, C.; Glenthoj, B.; Rizzo, R.; Debes, N.M.; Skov, L.; Brondum-Nielsen, K.; Paschou, P.; et al. Intragenic deletions affecting two alternative transcripts of the IMMP2L gene in patients with Tourette syndrome. Eur. J. Hum. Genet. 2014, 22, 1283-1289. [CrossRef]

49. Kohler, A.; Chen, B.; Gemignani, F.; Elisei, R.; Romei, C.; Figlioli, G.; Cipollini, M.; Cristaudo, A.; Bambi, F.; Hoffmann, P.; et al. Genome-wide association study on differentiated thyroid cancer. J. Clin. Endocrinol. Metab. 2013, 98, E1674-E1681. [CrossRef]

50. Kong, B.; Wang, Q.; Fung, E.; Xue, K.; Tsang, B.K. p53 Is Required for Cisplatin-induced Processing of the Mitochondrial Fusion Protein L-Opa1 That Is Mediated by the Mitochondrial Metallopeptidase Oma1 in Gynecologic Cancers. J. Biol. Chem. 2014, 289, 27134-27145. [CrossRef] 
51. Wu, Z.; Zuo, M.; Zeng, L.; Cui, K.; Liu, B.; Yan, C.; Chen, L.; Dong, J.; Shangguan, F.; Hu, W.; et al. OMA1 reprograms metabolism under hypoxia to promote colorectal cancer development. EMBO Rep. 2021, 22. [CrossRef]

52. Daverey, A.; Levytskyy, R.M.; Stanke, K.M.; Viana, M.P.; Swenson, S.; Hayward, S.L.; Narasimhan, M.; Khalimonchuk, O.; Kidambi, S. Depletion of mitochondrial protease OMA1 alters proliferative properties and promotes metastatic growth of breast cancer cells. Sci. Rep. 2019, 9. [CrossRef]

53. Saita, S.; Nolte, H.; Fiedler, K.U.; Kashkar, H.; Venne, A.S.; Zahedi, R.P.; Kruger, M.; Langer, T. PARL mediates Smac proteolytic maturation in mitochondria to promote apoptosis. Nat. Cell Biol. 2017, 19, 318-328. [CrossRef]

54. Karimi-Moghadam, A.; Charsouei, S.; Bell, B.; Jabalameli, M.R. Parkinson Disease from Mendelian Forms to Genetic Susceptibility: New Molecular Insights into the Neurodegeneration Process. Cell. Mol. Neurobiol. 2018, 38, 1153-1178. [CrossRef]

55. Yoshioka, H.; Katsu, M.; Sakata, H.; Okami, N.; Wakai, T.; Kinouchi, H.; Chan, P.H. The Role of Parl and HtrA2 in Striatal Neuronal Injury After Transient Global Cerebral Ischemia. J. Cereb. Blood Flow Metab. 2013, 33, 1658-1665. [CrossRef]

56. Civitarese, A.E.; Maclean, P.S.; Carling, S.; Kerr-Bayles, L.; Mcmillan, R.P.; Pierce, A.; Becker, T.C.; Moro, C.; Finlayson, J.; Lefort, N.; et al. Regulation of Skeletal Muscle Oxidative Capacity and Insulin Signaling by the Mitochondrial Rhomboid Protease PARL. Cell Metab. 2010, 11, 412-426. [CrossRef]

57. Spinazzi, M.; Radaelli, E.; Horre, K.; Arranz, A.M.; Gounko, N.V.; Agostinis, P.; Maia, T.M.; Impens, F.; Morais, V.A.; Lopez-Lluch, G.; et al. PARL deficiency in mouse causes Complex III defects, coenzyme Q depletion, and Leigh-like syndrome. Proc. Natl. Acad. Sci. USA 2019, 116, 277-286. [CrossRef]

58. Meissner, C.; Lorenz, H.; Hehn, B.; Lemberg, M.K. Intramembrane protease PARL defines a negative regulator of PINK1- and PARK2/Parkin-dependent mitophagy. Autophagy 2015, 11, 1484-1498. [CrossRef]

59. Saita, S.; Tatsuta, T.; Lampe, P.A.; Konig, T.; Ohba, Y.; Langer, T. PARL partitions the lipid transfer protein STARD7 between the cytosol and mitochondria. EMBO J. 2018, 37. [CrossRef]

60. Serero, A.; Giglione, C.; Sardini, A.; Martinez-Sanz, J.; Meinnel, T. An unusual peptide deformylase features in the human mitochondrial N-terminal methionine excision pathway. J. Biol. Chem. 2003, 278, 52953-52963. [CrossRef]

61. Leszczyniecka, M.; Bhatia, U.; Cueto, M.; Nirmala, N.R.; Towbin, H.; Vattay, A.; Wang, B.; Zabludoff, S.; Phillips, P.E. MAP1D, a novel methionine aminopeptidase family member is overexpressed in colon cancer. Oncogene 2006, 25, 3471-3478. [CrossRef] [PubMed]

62. Allan, C.M.; Awad, A.M.; Johnson, J.S.; Shirasaki, D.I.; Wang, C.; Blaby-Haas, C.E.; Merchant, S.S.; Loo, J.A.; Clarke, C.F. Identification of Coq11, a new coenzyme Q biosynthetic protein in the CoQ-synthome in Saccharomyces cerevisiae. J. Biol. Chem. 2015, 290, 7517-7534. [CrossRef] [PubMed]

63. Branda, S.S.; Isaya, G. Prediction and identification of new natural substrates of the yeast mitochondrial intermediate peptidase. J. Biol. Chem. 1995, 270, 27366-27373. [CrossRef] [PubMed]

64. Eldomery, M.K.; Akdemir, Z.C.; Vögtle, F.-N.; Charng, W.-L.; Mulica, P.; Rosenfeld, J.A.; Gambin, T.; Gu, S.; Burrage, L.C.; Al Shamsi, A.; et al. MIPEP recessive variants cause a syndrome of left ventricular non-compaction, hypotonia, and infantile death. Genome Med. 2016, 8. [CrossRef] [PubMed]

65. Gakh, O.; Cavadini, P.; Isaya, G. Mitochondrial processing peptidases. Biochim. Biophys. Acta 2002, 1592, 63-77. [CrossRef]

66. Vogtle, F.N.; Brandl, B.; Larson, A.; Pendziwiat, M.; Friederich, M.W.; White, S.M.; Basinger, A.; Kucukkose, C.; Muhle, H.; Jahn, J.A.; et al. Mutations in PMPCB Encoding the Catalytic Subunit of the Mitochondrial Presequence Protease Cause Neurodegeneration in Early Childhood. Am. J. Hum. Genet. 2018, 102, 557-573. [CrossRef] [PubMed]

67. Mossmann, D.; Meisinger, C.; Vogtle, F.N. Processing of mitochondrial presequences. Biochim. Biophys. Acta 2012, 1819, 1098-1106. [CrossRef]

68. O'Toole, J.F.; Liu, Y.; Davis, E.E.; Westlake, C.J.; Attanasio, M.; Otto, E.A.; Seelow, D.; Nurnberg, G.; Becker, C.; Nuutinen, M.; et al. Individuals with mutations in XPNPEP3, which encodes a mitochondrial protein, develop a nephronophthisis-like nephropathy. J. Clin. Investig. 2010, 120, 791-802. [CrossRef]

69. Mirali, S.; Botham, A.; Voisin, V.; Xu, C.; St-Germain, J.; Sharon, D.; Hoff, F.W.; Qiu, Y.; Hurren, R.; Gronda, M.; et al. The mitochondrial peptidase, neurolysin, regulates respiratory chain supercomplex formation and is necessary for AML viability. Sci. Transl. Med. 2020, 12. [CrossRef]

70. Brunetti, D.; Torsvik, J.; Dallabona, C.; Teixeira, P.; Sztromwasser, P.; Fernandez-Vizarra, E.; Cerutti, R.; Reyes, A.; Preziuso, C.; D'Amati, G.; et al. Defective PITRM1 mitochondrial peptidase is associated with A $\beta$ amyloidotic neurodegeneration. EMBO Mol. Med. 2016, 8, 176-190. [CrossRef]

71. Falkevall, A.; Alikhani, N.; Bhushan, S.; Pavlov, P.F.; Busch, K.; Johnson, K.A.; Eneqvist, T.; Tjernberg, L.; Ankarcrona, M.; Glaser, E. Degradation of the Amyloid $\beta$-Protein by the Novel Mitochondrial Peptidasome, PreP. J. Biol. Chem. 2006, 281, 29096-29104. [CrossRef]

72. Canet-Avilés, R.M.; Wilson, M.A.; Miller, D.W.; Ahmad, R.; Mclendon, C.; Bandyopadhyay, S.; Baptista, M.J.; Ringe, D.; Petsko, G.A.; Cookson, M.R. The Parkinson's disease protein DJ-1 is neuroprotective due to cysteine-sulfinic acid-driven mitochondrial localization. Proc. Natl. Acad. Sci. USA 2004, 101, 9103-9108. [CrossRef] [PubMed]

73. Wang, X.; Petrie, T.G.; Liu, Y.; Liu, J.; Fujioka, H.; Zhu, X. Parkinson's disease-associated DJ-1 mutations impair mitochondrial dynamics and cause mitochondrial dysfunction. J. Neurochem. 2012, 121, 830-839. [CrossRef]

74. Bonifati, V. Mutations in the DJ-1 Gene Associated with Autosomal Recessive Early-Onset Parkinsonism. Science 2003, 299, 256-259. [CrossRef] 
75. Bandopadhyay, R. The expression of DJ-1 (PARK7) in normal human CNS and idiopathic Parkinson's disease. Brain 2004, 127, 420-430. [CrossRef]

76. Vasseur, S.; Afzal, S.; Tardivel-Lacombe, J.; Park, D.S.; Iovanna, J.L.; Mak, T.W. DJ-1/PARK7 is an important mediator of hypoxia-induced cellular responses. Proc. Natl. Acad. Sci. USA 2009, 106, 1111-1116. [CrossRef]

77. Abd El Atti, R.M.; Abou Gabal, H.H.; Osman, W.M.; Saad, A.S. Insights into the prognostic value of DJ-1 and MIB-1 in astrocytic tumors. Diagn. Pathol. 2013, 8, 126. [CrossRef]

78. Kim, R.H.; Peters, M.; Jang, Y.; Shi, W.; Pintilie, M.; Fletcher, G.C.; Deluca, C.; Liepa, J.; Zhou, L.; Snow, B.; et al. DJ-1, a novel regulator of the tumor suppressor PTEN. Cancer Cell 2005, 7, 263-273. [CrossRef]

79. Bunkholt Elstrand, M.; Dong, H.P.; Ødegaard, E.; Holth, A.; Elloul, S.; Reich, R.; Tropé, C.G.; Davidson, B. Mammalian target of rapamycin is a biomarker of poor survival in metastatic serous ovarian carcinoma. Hum. Pathol. 2010, 41, 794-804. [CrossRef]

80. Hod, Y. Differential control of apoptosis by DJ-1 in prostate benign and cancer cells. J. Cell. Biochem. 2004, 92, 1221-1233. [CrossRef]

81. Jin, W. Novel Insights into PARK7 (DJ-1), a Potential Anti-Cancer Therapeutic Target, and Implications for Cancer Progression. J. Clin. Med. 2020, 9, 1256. [CrossRef] [PubMed]

82. Dvořáková-Holá, K.; Matušková, A.; Kubala, M.; Otyepka, M.; Kučera, T.; Večeř, J.; Heřman, P.; Parkhomenko, N.; Kutejova, E.; Janata, J. Glycine-Rich Loop of Mitochondrial Processing Peptidase $\alpha$-Subunit Is Responsible for Substrate Recognition by a Mechanism Analogous to Mitochondrial Receptor Tom20. J. Mol. Biol. 2010, 396, 1197-1210. [CrossRef] [PubMed]

83. Jobling, R.K.; Assoum, M.; Gakh, O.; Blaser, S.; Raiman, J.A.; Mignot, C.; Roze, E.; Dürr, A.; Brice, A.; Lévy, N.; et al. PMPCAmutations cause abnormal mitochondrial protein processing in patients with non-progressive cerebellar ataxia. Brain 2015, 138, 1505-1517. [CrossRef] [PubMed]

84. Smith, P.M.; Fox, J.L.; Winge, D.R. Reprint of: Biogenesis of the cytochrome bc1 complex and role of assembly factors. Biochim. Biophys. Acta Bioenerg. 2012, 1817, 872-882. [CrossRef]

85. Kriaucionis, S.; Paterson, A.; Curtis, J.; Guy, J.; Macleod, N.; Bird, A. Gene Expression Analysis Exposes Mitochondrial Abnormalities in a Mouse Model of Rett Syndrome. Mol Cell Biol 2006, 26, 5033-5042. [CrossRef]

86. Kunej, T.; Wang, Z.; Michal, J.J.; Daniels, T.F.; Magnuson, N.S.; Jiang, Z. Functional UQCRC1 Polymorphisms Affect Promoter Activity and Body Lipid Accumulation. Obesity 2007, 15, 2896-2901. [CrossRef] [PubMed]

87. Kulawiec, M.; Arnouk, H. Proteomic analysis of proteins involved in mitochondria-to-nucleus retrograde response in human cancer cells. Cancer Biol. Ther. 2006, 5, 967-975. [CrossRef]

88. Wang, Q.; Li, M.; Gan, Y.; Jiang, S.; Qiao, J.; Zhang, W.; Fan, Y.; Shen, Y.; Song, Y.; Meng, Z.; et al. Mitochondrial Protein UQCRC1 is Oncogenic and a Potential Therapeutic Target for Pancreatic Cancer. Theranostics 2020, 10, 2141-2157. [CrossRef] [PubMed]

89. Ellinger, J.; Gromes, A.; Poss, M.; Brüggemann, M.; Schmidt, D.; Ellinger, N.; Tolkach, Y.; Dietrich, D.; Kristiansen, G.; Müller, S.C. Systematic expression analysis of the mitochondrial complex III subunits identifies UQCRC1 as biomarker in clear cell renal cell carcinoma. Oncotarget 2016, 7, 86490-86499. [CrossRef] [PubMed]

90. Miyake, N.; Yano, S.; Sakai, C.; Hatakeyama, H.; Matsushima, Y.; Shiina, M.; Watanabe, Y.; Bartley, J.; Abdenur, J.E.; Wang, R.Y.; et al. Mitochondrial Complex III Deficiency Caused by a HomozygousUQCRC2Mutation Presenting with Neonatal-Onset Recurrent Metabolic Decompensation. Hum. Mutat. 2013, 34, 446-452. [CrossRef]

91. Gaignard, P.; Eyer, D.; Lebigot, E.; Oliveira, C.; Therond, P.; Boutron, A.; Slama, A. UQCRC2 mutation in a patient with mitochondrial complex III deficiency causing recurrent liver failure, lactic acidosis and hypoglycemia. J. Hum. Genet. 2017, 62, 729-731. [CrossRef]

92. Shang, Y.; Zhang, F.; Li, D.; Li, C.; Li, H.; Jiang, Y.; Zhang, D. Overexpression of UQCRC2 is correlated with tumor progression and poor prognosis in colorectal cancer. Pathol. Res. Pract. 2018, 214, 1613-1620. [CrossRef]

93. Araujo, T.K.D.; Secolin, R.; Félix, T.M.; Souza, L.T.D.; Fontes, M.Í.B.; Monlleó, I.L.; Souza, J.D.; Fett-Conte, A.C.; Ribeiro, E.M.; Xavier, A.C.; et al. A multicentric association study between 39 genes and nonsyndromic cleft lip and palate in a Brazilian population. J. Cranio-Maxillofac. Surg. 2016, 44, 16-20. [CrossRef]

94. Li, S.-H.; Lin, M.-H.; Hwu, Y.-M.; Lu, C.-H.; Yeh, L.-Y.; Chen, Y.-J.; Lee, R.K.-K. Correlation of cumulus gene expression of GJA1, PRSS35, PTX3, and SERPINE2 with oocyte maturation, fertilization, and embryo development. Reprod. Biol. Endocrinol. 2015, 13. [CrossRef]

95. Lebleu, V.S.; Teng, Y.; O'Connell, J.T.; Charytan, D.; Müller, G.A.; Müller, C.A.; Sugimoto, H.; Kalluri, R. Identification of human epididymis protein-4 as a fibroblast-derived mediator of fibrosis. Nat. Med. 2013, 19, 227-231. [CrossRef]

96. Papa, L.; Germain, D. Estrogen receptor mediates a distinct mitochondrial unfolded protein response. J. Cell Sci. 2011, 124, 1396-1402. [CrossRef]

97. Radke, S.; Chander, H.; Schafer, P.; Meiss, G.; Kruger, R.; Schulz, J.B.; Germain, D. Mitochondrial protein quality control by the proteasome involves ubiquitination and the protease Omi. J. Biol. Chem. 2008, 283, 12681-12685. [CrossRef]

98. Soyama, H.; Miyamoto, M.; Takano, M.; Aoyama, T.; Matsuura, H.; Sakamoto, T.; Takasaki, K.; Kuwahara, M.; Kato, K.; Yoshikawa, T.; et al. Ovarian serous carcinomas acquire cisplatin resistance and increased invasion through downregulation of the high-temperature-required protein A2 (HtrA2), following repeated treatment with cisplatin. Med. Oncol. 2017, 34. [CrossRef]

99. Bogaerts, V.; Nuytemans, K.; Reumers, J.; Pals, P.; Engelborghs, S.; Pickut, B.; Corsmit, E.; Peeters, K.; Schymkowitz, J.; De Deyn, P.P.; et al. Genetic variability in the mitochondrial serine protease HTRA2 contributes to risk for Parkinson disease. Hum. Mutat. 2008, 29, 832-840. [CrossRef] 
100. Botham, A.; Coyaud, E.; Nirmalanandhan, V.S.; Gronda, M.; Hurren, R.; Maclean, N.; St-Germain, J.; Mirali, S.; Laurent, E.; Raught, B.; et al. Global Interactome Mapping of Mitochondrial Intermembrane Space Proteases Identifies a Novel Function for HTRA2. Proteomics 2019, 19, e1900139. [CrossRef]

101. Eriksson, O.; Lalowski, M.; Lindholm, D. Commentary: LACTB is a tumour suppressor that modulates lipid metabolism and cell state. Front. Physiol. 2017, 8, 396. [CrossRef] [PubMed]

102. Zeng, K.; Chen, X.; Hu, X.; Liu, X.; Xu, T.; Sun, H.; Pan, Y.; He, B.; Wang, S. LACTB, a novel epigenetic silenced tumor suppressor, inhibits colorectal cancer progression by attenuating MDM2-mediated p53 ubiquitination and degradation. Oncogene 2018, 37, 5534-5551. [CrossRef] [PubMed]

103. Xue, C.; He, Y.; Zhu, W.; Chen, X.; Yu, Y.; Hu, Q.; Chen, J.; Liu, L.; Ren, F.; Ren, Z.; et al. Low expression of LACTB promotes tumor progression and predicts poor prognosis in hepatocellular carcinoma. Am. J. Transl. Res. 2018, 10, 4152-4162. [PubMed]

104. Keckesova, Z.; Donaher, J.L.; De Cock, J.; Freinkman, E.; Lingrell, S.; Bachovchin, D.A.; Bierie, B.; Tischler, V.; Noske, A.; Okondo, M.C.; et al. LACTB is a tumour suppressor that modulates lipid metabolism and cell state. Nature 2017, 543, 681-686. [CrossRef] [PubMed]

105. Stiburek, L.; Cesnekova, J.; Kostkova, O.; Fornuskova, D.; Vinsova, K.; Wenchich, L.; Houstek, J.; Zeman, J. YME1L controls the accumulation of respiratory chain subunits and is required for apoptotic resistance, cristae morphogenesis, and cell proliferation. Mol. Biol. Cell 2012, 23, 1010-1023. [CrossRef]

106. Levytskyy, R.M.; Bohovych, I.; Khalimonchuk, O. Metalloproteases of the Inner Mitochondrial Membrane. Biochemistry 2017, 56, 4737-4746. [CrossRef]

107. Shi, H.; Rampello, A.J.; Glynn, S.E. Engineered AAA+ proteases reveal principles of proteolysis at the mitochondrial inner membrane. Nat. Commun. 2016, 7, 13301. [CrossRef]

108. Rainbolt, T.K.; Lebeau, J.; Puchades, C.; Wiseman, R.L. Reciprocal Degradation of YME1L and OMA1 Adapts Mitochondrial Proteolytic Activity during Stress. Cell Rep. 2016, 14, 2041-2049. [CrossRef]

109. Suppanz, I.E.; Wurm, C.A.; Wenzel, D.; Jakobs, S. The m-AAA protease processes cytochrome c peroxidase preferentially at the inner boundary membrane of mitochondria. Mol. Biol. Cell 2009, 20, 572-580. [CrossRef]

110. Atorino, L.; Silvestri, L.; Koppen, M.; Cassina, L.; Ballabio, A.; Marconi, R.; Langer, T.; Casari, G. Loss of m-AAA protease in mitochondria causes complex I deficiency and increased sensitivity to oxidative stress in hereditary spastic paraplegia. J. Cell Biol. 2003, 163, 777-787. [CrossRef]

111. Casari, G.; De Fusco, M.; Ciarmatori, S.; Zeviani, M.; Mora, M.; Fernandez, P.; De Michele, G.; Filla, A.; Cocozza, S.; Marconi, R.; et al. Spastic paraplegia and OXPHOS impairment caused by mutations in paraplegin, a nuclear-encoded mitochondrial metalloprotease. Cell 1998, 93, 973-983. [CrossRef]

112. Almajan, E.R.; Richter, R.; Paeger, L.; Martinelli, P.; Barth, E.; Decker, T.; Larsson, N.G.; Kloppenburg, P.; Langer, T.; Rugarli, E.I. AFG3L2 supports mitochondrial protein synthesis and Purkinje cell survival. J. Clin. Investig. 2012, 122, 4048-4058. [CrossRef]

113. Goard, C.A.; Schimmer, A.D. Mitochondrial matrix proteases as novel therapeutic targets in malignancy. Oncogene 2014, 33, 2690-2699. [CrossRef]

114. Koppen, M.; Metodiev, M.D.; Casari, G.; Rugarli, E.I.; Langer, T. Variable and tissue-specific subunit composition of mitochondrial m-AAA protease complexes linked to hereditary spastic paraplegia. Mol. Cell. Biol. 2007, 27, 758-767. [CrossRef]

115. Bota, D.A.; Davies, K.J. Lon protease preferentially degrades oxidized mitochondrial aconitase by an ATP-stimulated mechanism. Nat. Cell Biol. 2002, 4, 674-680. [CrossRef]

116. Bulteau, A.L.; Mena, N.P.; Auchère, F.; Lee, I.; Prigent, A.; Lobsiger, C.S.; Camadro, J.M.; Hirsch, E.C. Dysfunction of mitochondrial Lon protease and identification of oxidized protein in mouse brain following exposure to MPTP: Implications for Parkinson disease. Free Radic. Biol. Med. 2017, 108, 236-246. [CrossRef]

117. Pryde, K.R.; Taanman, J.W.; Schapira, A.H. A LON-ClpP Proteolytic Axis Degrades Complex I to Extinguish ROS Production in Depolarized Mitochondria. Cell Rep. 2016, 17, 2522-2531. [CrossRef]

118. Bezawork-Geleta, A.; Saiyed, T.; Dougan, D.A.; Truscott, K.N. Mitochondrial matrix proteostasis is linked to hereditary paraganglioma: LON-mediated turnover of the human flavinylation factor SDH5 is regulated by its interaction with SDHA. FASEB J. 2014, 28, 1794-1804. [CrossRef]

119. Fukuda, R.; Zhang, H.; Kim, J.W.; Shimoda, L.; Dang, C.V.; Semenza, G.L. HIF-1 regulates cytochrome oxidase subunits to optimize efficiency of respiration in hypoxic cells. Cell 2007, 129, 111-122. [CrossRef]

120. Kita, K.; Suzuki, T.; Ochi, T. Diphenylarsinic acid promotes degradation of glutaminase C by mitochondrial Lon protease. J. Biol. Chem. 2012, 287, 18163-18172. [CrossRef]

121. Granot, Z.; Kobiler, O.; Melamed-Book, N.; Eimerl, S.; Bahat, A.; Lu, B.; Braun, S.; Maurizi, M.R.; Suzuki, C.K.; Oppenheim, A.B.; et al. Turnover of mitochondrial steroidogenic acute regulatory (StAR) protein by Lon protease: The unexpected effect of proteasome inhibitors. Mol. Endocrinol. 2007, 21, 2164-2177. [CrossRef] [PubMed]

122. Teng, H.; Wu, B.; Zhao, K.; Yang, G.; Wu, L.; Wang, R. Oxygen-sensitive mitochondrial accumulation of cystathionine $\beta$-synthase mediated by Lon protease. Proc. Natl. Acad. Sci. USA 2013, 110, 12679-12684. [CrossRef] [PubMed]

123. Tian, Q.; Li, T.; Hou, W.; Zheng, J.; Schrum, L.W.; Bonkovsky, H.L. Lon peptidase 1 (LONP1)-dependent breakdown of mitochondrial 5-aminolevulinic acid synthase protein by heme in human liver cells. J. Biol. Chem. 2011, 286, 26424-26430. [CrossRef] [PubMed] 
124. Lu, B.; Lee, J.; Nie, X.; Li, M.; Morozov, Y.I.; Venkatesh, S.; Bogenhagen, D.F.; Temiakov, D.; Suzuki, C.K. Phosphorylation of human TFAM in mitochondria impairs DNA binding and promotes degradation by the AAA+ Lon protease. Mol. Cell 2013, 49, 121-132. [CrossRef] [PubMed]

125. Matsushima, Y.; Goto, Y.; Kaguni, L.S. Mitochondrial Lon protease regulates mitochondrial DNA copy number and transcription by selective degradation of mitochondrial transcription factor A (TFAM). Proc. Natl. Acad. Sci. USA 2010, 107, 18410-18415. [CrossRef]

126. Corydon, T.J.; Wilsbech, M.; Jespersgaard, C.; Andresen, B.S.; Borglum, A.D.; Pedersen, S.; Bolund, L.; Gregersen, N.; Bross, P. Human and mouse mitochondrial orthologs of bacterial ClpX. Mamm. Genome 2000, 11, 899-905. [CrossRef]

127. Yu, A.Y.; Houry, W.A. ClpP: A distinctive family of cylindrical energy-dependent serine proteases. FEBS Lett. 2007, 581, 3749-3757. [CrossRef]

128. Fischer, F.; Langer, J.D.; Osiewacz, H.D. Identification of potential mitochondrial CLPXP protease interactors and substrates suggests its central role in energy metabolism. Sci. Rep. 2015, 5, 18375. [CrossRef]

129. Kang, S.G.; Dimitrova, M.N.; Ortega, J.; Ginsburg, A.; Maurizi, M.R. Human mitochondrial ClpP is a stable heptamer that assembles into a tetradecamer in the presence of ClpX. J. Biol. Chem. 2005, 280, 35424-35432. [CrossRef]

130. Stahl, M.; Sieber, S.A. An amino acid domino effect orchestrates ClpP's conformational states. Curr. Opin. Chem. Biol. 2017, 40, 102-110. [CrossRef]

131. Liu, K.; Ologbenla, A.; Houry, W.A. Dynamics of the ClpP serine protease: A model for self-compartmentalized proteases. Crit. Rev. Biochem. Mol. Biol. 2014, 49, 400-412. [CrossRef]

132. Gispert, S.; Parganlija, D.; Klinkenberg, M.; Drose, S.; Wittig, I.; Mittelbronn, M.; Grzmil, P.; Koob, S.; Hamann, A.; Walter, M.; et al. Loss of mitochondrial peptidase Clpp leads to infertility, hearing loss plus growth retardation via accumulation of CLPX, mtDNA and inflammatory factors. Hum. Mol. Genet. 2013, 22, 4871-4887. [CrossRef]

133. Amor, A.J.; Schmitz, K.R.; Baker, T.A.; Sauer, R.T. Roles of the ClpX IGF loops in ClpP association, dissociation, and protein degradation. Protein Sci. 2019, 28, 756-765. [CrossRef]

134. Kang, S.G.; Maurizi, M.R.; Thompson, M.; Mueser, T.; Ahvazi, B. Crystallography and mutagenesis point to an essential role for the N-terminus of human mitochondrial ClpP. J. Struct. Biol. 2004, 148, 338-352. [CrossRef]

135. Baker, T.A.; Sauer, R.T. ClpXP, an ATP-powered unfolding and protein-degradation machine. Biochim. Biophys. Acta 2012, 1823, 15-28. [CrossRef]

136. Ripstein, Z.A.; Vahidi, S.; Houry, W.A.; Rubinstein, J.L.; Kay, L.E. A processive rotary mechanism couples substrate unfolding and proteolysis in the ClpXP degradation machinery. eLife 2020, 9, e52158. [CrossRef]

137. Sauer, R.T.; Baker, T.A. AAA+ proteases: ATP-fueled machines of protein destruction. Annu. Rev. Biochem. 2011, 80, 587-612. [CrossRef]

138. Battesti, A.; Gottesman, S. Roles of adaptor proteins in regulation of bacterial proteolysis. Curr. Opin. Microbiol. 2013, 16, 140-147. [CrossRef]

139. Fischer, F.; Hamann, A.; Osiewacz, H.D. Mitochondrial quality control: An integrated network of pathways. Trends Biochem. Sci. 2012, 37, 284-292. [CrossRef]

140. Kardon, J.R.; Moroco, J.A.; Engen, J.R.; Baker, T.A. Mitochondrial ClpX activates an essential biosynthetic enzyme through partial unfolding. eLife 2020, 9, e54387. [CrossRef]

141. Kasashima, K.; Sumitani, M.; Endo, H. Maintenance of mitochondrial genome distribution by mitochondrial AAA+ protein ClpX. Exp. Cell Res. 2012, 318, 2335-2343. [CrossRef] [PubMed]

142. Shpilka, T.; Haynes, C.M. The mitochondrial UPR: Mechanisms, physiological functions and implications in ageing. Nat. Rev. Mol. Cell Biol. 2018, 19, 109-120. [CrossRef] [PubMed]

143. Haynes, C.M.; Yang, Y.; Blais, S.P.; Neubert, T.A.; Ron, D. The matrix peptide exporter HAF-1 signals a mitochondrial UPR by activating the transcription factor ZC376.7 in C. elegans. Mol. Cell 2010, 37, 529-540. [CrossRef] [PubMed]

144. Bota, D.A.; Ngo, J.K.; Davies, K.J. Downregulation of the human Lon protease impairs mitochondrial structure and function and causes cell death. Free Radic. Biol. Med. 2005, 38, 665-677. [CrossRef]

145. Liu, Y.; Lan, L.; Huang, K.; Wang, R.; Xu, C.; Shi, Y.; Wu, X.; Wu, Z.; Zhang, J.; Chen, L.; et al. Inhibition of Lon blocks cell proliferation, enhances chemosensitivity by promoting apoptosis and decreases cellular bioenergetics of bladder cancer: Potential roles of Lon as a prognostic marker and therapeutic target in baldder cancer. Oncotarget 2014, 5, 11209-11224. [CrossRef]

146. Gibellini, L.; Pinti, M.; Bartolomeo, R.; De Biasi, S.; Cormio, A.; Musicco, C.; Carnevale, G.; Pecorini, S.; Nasi, M.; De Pol, A.; et al. Inhibition of Lon protease by triterpenoids alters mitochondria and is associated to cell death in human cancer cells. Oncotarget 2015, 6, 25466-25483. [CrossRef]

147. Speranza, G.; Gutierrez, M.E.; Kummar, S.; Strong, J.M.; Parker, R.J.; Collins, J.; Yu, Y.; Cao, L.; Murgo, A.J.; Doroshow, J.H.; et al. Phase I study of the synthetic triterpenoid, 2-cyano-3, 12-dioxoolean-1, 9-dien-28-oic acid (CDDO), in advanced solid tumors. Cancer Chemother. Pharmacol. 2012, 69, 431-438. [CrossRef]

148. Tsao, T.; Kornblau, S.; Safe, S.; Watt, J.C.; Ruvolo, V.; Chen, W.; Qiu, Y.; Coombes, K.R.; Ju, Z.; Abdelrahim, M.; et al. Role of peroxisome proliferator-activated receptor-gamma and its coactivator DRIP205 in cellular responses to CDDO (RTA-401) in acute myelogenous leukemia. Cancer Res. 2010, 70, 4949-4960. [CrossRef]

149. Cheng, K.C.; Hsueh, M.C.; Chang, H.C.; Lee, A.Y.; Wang, H.M.; Chen, C.Y. Antioxidants from the leaves of Cinnamomum kotoense. Nat. Prod. Commun. 2010, 5, 911-912. [CrossRef] 
150. Dikoglu, E.; Alfaiz, A.; Gorna, M.; Bertola, D.; Chae, J.H.; Cho, T.J.; Derbent, M.; Alanay, Y.; Guran, T.; Kim, O.H.; et al. Mutations in LONP1, a mitochondrial matrix protease, cause CODAS syndrome. Am. J. Med. Genet. Part A 2015, 167, 1501-1509. [CrossRef]

151. Yien, Y.Y.; Ducamp, S.; van der Vorm, L.N.; Kardon, J.R.; Manceau, H.; Kannengiesser, C.; Bergonia, H.A.; Kafina, M.D.; Karim, Z.; Gouya, L.; et al. Mutation in human CLPX elevates levels of $\delta$-aminolevulinate synthase and protoporphyrin IX to promote erythropoietic protoporphyria. Proc. Natl. Acad. Sci. USA 2017, 114, E8045-E8052. [CrossRef]

152. Ngo, J.K.; Pomatto, L.C.; Davies, K.J. Upregulation of the mitochondrial Lon Protease allows adaptation to acute oxidative stress but dysregulation is associated with chronic stress, disease, and aging. Redox Biol. 2013, 1, 258-264. [CrossRef]

153. Brodie, E.J.; Zhan, H.; Saiyed, T.; Truscott, K.N.; Dougan, D.A. Perrault syndrome type 3 caused by diverse molecular defects in CLPP. Sci. Rep. 2018, 8, 12862. [CrossRef]

154. Wallace, D.C. Mitochondria and cancer. Nat. Rev. Cancer 2012, 12, 685-698. [CrossRef]

155. Porporato, P.E.; Filigheddu, N.; Pedro, J.M.B.-S.; Kroemer, G.; Galluzzi, L. Mitochondrial metabolism and cancer. Cell Res. 2018, 28, 265-280. [CrossRef]

156. Pollyea, D.A.; Stevens, B.M.; Jones, C.L.; Winters, A.; Pei, S.; Minhajuddin, M.; D’Alessandro, A.; Culp-Hill, R.; Riemondy, K.A.; Gillen, A.E.; et al. Venetoclax with azacitidine disrupts energy metabolism and targets leukemia stem cells in patients with acute myeloid leukemia. Nat. Med. 2018, 24, 1859-1866. [CrossRef]

157. Skrtić, M.; Sriskanthadevan, S.; Jhas, B.; Gebbia, M.; Wang, X.; Wang, Z.; Hurren, R.; Jitkova, Y.; Gronda, M.; Maclean, N.; et al. Inhibition of mitochondrial translation as a therapeutic strategy for human acute myeloid leukemia. Cancer Cell 2011, 20, 674-688. [CrossRef]

158. SSriskanthadevan, S.; Jeyaraju, D.V.; Chung, T.E.; Prabha, S.; Xu, W.; Skrtic, M.; Jhas, B.; Hurren, R.; Gronda, M.; Wang, X.; et al. AML cells have low spare reserve capacity in their respiratory chain that renders them susceptible to oxidative metabolic stress. Blood 2015, 125, 2120-2130. [CrossRef]

159. Kuntz, E.M.; Baquero, P.; Michie, A.M.; Dunn, K.; Tardito, S.; Holyoake, T.L.; Helgason, G.V.; Gottlieb, E. Targeting mitochondrial oxidative phosphorylation eradicates therapy-resistant chronic myeloid leukemia stem cells. Nat. Med. 2017, 23, 1234-1240. [CrossRef]

160. Lagadinou, E.D.; Sach, A.; Callahan, K.; Rossi, R.M.; Neering, S.J.; Minhajuddin, M.; Ashton, J.M.; Pei, S.; Grose, V.; O’Dwyer, K.M.; et al. BCL-2 inhibition targets oxidative phosphorylation and selectively eradicates quiescent human leukemia stem cells. Cell Stem Cell 2013, 12, 329-341. [CrossRef]

161. Viale, A.; Pettazzoni, P.; Lyssiotis, C.A.; Ying, H.; Sánchez, N.; Marchesini, M.; Carugo, A.; Green, T.; Seth, S.; Giuliani, V.; et al. Oncogene ablation-resistant pancreatic cancer cells depend on mitochondrial function. Nature 2014, 514, 628-632. [CrossRef] [PubMed]

162. Ghosh, P.; Vidal, C.; Dey, S.; Zhang, L. Mitochondria Targeting as an Effective Strategy for Cancer Therapy. Int. J. Mol. Sci. 2020, 21, 3363. [CrossRef] [PubMed]

163. Sharon, D.; Cathelin, S.; Mirali, S.; Di Trani, J.M.; Yanofsky, D.J.; Keon, K.A.; Rubinstein, J.L.; Schimmer, A.D.; Ketela, T.; Chan, S.M. Inhibition of mitochondrial translation overcomes venetoclax resistance in AML through activation of the integrated stress response. Sci. Transl. Med. 2019, 11. [CrossRef] [PubMed]

164. Lebleu, V.S.; O'Connell, J.T.; Gonzalez Herrera, K.N.; Wikman, H.; Pantel, K.; Haigis, C.; Marcia, M.C.; De Carvalho, F.M.; Damascena, A.; Domingos Chinen, L.T.; et al. PGC-1 $\alpha$ mediates mitochondrial biogenesis and oxidative phosphorylation in cancer cells to promote metastasis. Nat. Cell Biol. 2014, 16, 992-1003. [CrossRef] [PubMed]

165. Böttcher, T.; Sieber, S.A. $\beta$-Lactones as Privileged Structures for the Active-Site Labeling of Versatile Bacterial Enzyme Classes. Angew. Chem. Int. Ed. 2008, 47, 4600-4603. [CrossRef] [PubMed]

166. Gersch, M.; Gut, F.; Korotkov, V.S.; Lehmann, J.; Böttcher, T.; Rusch, M.; Hedberg, C.; Waldmann, H.; Klebe, G.; Sieber, S.A. The Mechanism of Caseinolytic Protease (ClpP) Inhibition. Angew. Chem. Int. Ed. 2013, 52, 3009-3014. [CrossRef]

167. Böttcher, T.; Sieber, S.A. $\beta$-Lactams and $\beta$-lactones as activity-based probes in chemical biology. MedChemComm 2012, 3, 408-417. [CrossRef]

168. Hackl, M.W.; Lakemeyer, M.; Dahmen, M.; Glaser, M.; Pahl, A.; Lorenz-Baath, K.; Menzel, T.; Sievers, S.; Bottcher, T.; Antes, I.; et al. Phenyl Esters Are Potent Inhibitors of Caseinolytic Protease P and Reveal a Stereogenic Switch for Deoligomerization. J. Am. Chem. Soc. 2015, 137, 8475-8483. [CrossRef]

169. Gronauer, T.F.; Mandl, M.M.; Lakemeyer, M.; Hackl, M.W.; Messner, M.; Korotkov, V.S.; Pachmayr, J.; Sieber, S.A. Design and synthesis of tailored human caseinolytic protease P inhibitors. Chem. Commun. 2018, 54, 9833-9836. [CrossRef]

170. Knott, K.; Fishovitz, J.; Thorpe, S.B.; Lee, I.; Santos, W.L. N-Terminal peptidic boronic acids selectively inhibit human ClpXP. Org. Biomol. Chem. 2010, 8, 3451-3456. [CrossRef]

171. Tan, J.; Grouleff, J.J.; Jitkova, Y.; Diaz, D.B.; Griffith, E.C.; Shao, W.; Bogdanchikova, A.F.; Poda, G.; Schimmer, A.D.; Lee, R.E.; et al. De Novo Design of Boron-Based Peptidomimetics as Potent Inhibitors of Human ClpP in the Presence of Human ClpX. J Med. Chem. 2019, 62, 6377-6390. [CrossRef]

172. Karl, H.; Michel, R.E.K. A54556 antibiotics and process for production thereof. U.S. Patent No. 4,492,650, 8 January 1985.

173. Lee, B.G.; Park, E.Y.; Lee, K.E.; Jeon, H.; Sung, K.H.; Paulsen, H.; Rubsamen-Schaeff, H.; Brotz-Oesterhelt, H.; Song, H.K. Structures of $\mathrm{ClpP}$ in complex with acyldepsipeptide antibiotics reveal its activation mechanism. Nat. Struct. Mol. Biol. 2010, 17, 471-478. [CrossRef] 
174. Li, D.H.; Chung, Y.S.; Gloyd, M.; Joseph, E.; Ghirlando, R.; Wright, G.D.; Cheng, Y.Q.; Maurizi, M.R.; Guarne, A.; Ortega, J. Acyldepsipeptide antibiotics induce the formation of a structured axial channel in ClpP: A model for the ClpX/ClpA-bound state of ClpP. Chem. Biol. 2010, 17, 959-969. [CrossRef]

175. Brotz-Oesterhelt, H.; Beyer, D.; Kroll, H.P.; Endermann, R.; Ladel, C.; Schroeder, W.; Hinzen, B.; Raddatz, S.; Paulsen, H.; Henninger, K.; et al. Dysregulation of bacterial proteolytic machinery by a new class of antibiotics. Nat. Med. 2005, 11, 1082-1087. [CrossRef]

176. Wong, K.S.; Mabanglo, M.F.; Seraphim, T.V.; Mollica, A.; Mao, Y.Q.; Rizzolo, K.; Leung, E.; Moutaoufik, M.T.; Hoell, L.; Phanse, S.; et al. Acyldepsipeptide Analogs Dysregulate Human Mitochondrial ClpP Protease Activity and Cause Apoptotic Cell Death. Cell Chem. Biol. 2018, 25, 1017-1030.e1019. [CrossRef]

177. Carter, J.L.; Hege, K.; Kalpage, H.A.; Edwards, H.; Huttemann, M.; Taub, J.W.; Ge, Y. Targeting mitochondrial respiration for the treatment of acute myeloid leukemia. Biochem. Pharm. 2020, 182, 114253. [CrossRef]

178. Prabhu, V.V.; Morrow, S.; Rahman Kawakibi, A.; Zhou, L.; Ralff, M.; Ray, J.; Jhaveri, A.; Ferrarini, I.; Lee, Y.; Parker, C.; et al. ONC201 and imipridones: Anti-cancer compounds with clinical efficacy. Neoplasia 2020, 22, 725-744. [CrossRef]

179. Kurz, S.C.; Tarapore, R.; Odia, Y.; Butowski, N.A.; Koschmann, C.J.; Aguilera, D.; MacDonald, T.J.; Lu, G.; Allen, J.E.; Oster, W.; et al. Clinical experience of ONC201 in patients with recurrent H3 K27M-mutant spinal cord glioma. J. Clin. Oncol. 2020, $38,2563$. [CrossRef]

180. Arrillaga-Romany, I.; Odia, Y.; Prabhu, V.V.; Tarapore, R.S.; Merdinger, K.; Stogniew, M.; Oster, W.; Allen, J.E.; Mehta, M.; Batchelor, T.T.; et al. Biological activity of weekly ONC201 in adult recurrent glioblastoma patients. Neuro Oncol. 2020, $22,94-102$. [CrossRef]

181. Ralff, M.D.; Jhaveri, A.; Ray, J.E.; Zhou, L.; Lev, A.; Campbell, K.S.; Dicker, D.T.; Ross, E.A.; El-Deiry, W.S. TRAIL receptor agonists convert the response of breast cancer cells to ONC201 from anti-proliferative to apoptotic. Oncotarget 2020, 11, 3753-3769. [CrossRef]

182. Pruss, M.; Dwucet, A.; Tanriover, M.; Hlavac, M.; Kast, R.E.; Debatin, K.M.; Wirtz, C.R.; Halatsch, M.E.; Siegelin, M.D.; Westhoff, M.A.; et al. Dual metabolic reprogramming by ONC201/TIC10 and 2-Deoxyglucose induces energy depletion and synergistic anti-cancer activity in glioblastoma. Br. J. Cancer 2020, 122, 1146-1157. [CrossRef]

183. Greer, Y.E.; Porat-Shliom, N.; Nagashima, K.; Stuelten, C.; Crooks, D.; Koparde, V.N.; Gilbert, S.F.; Islam, C.; Ubaldini, A.; Ji, Y.; et al. ONC201 kills breast cancer cells in vitro by targeting mitochondria. Oncotarget 2018, 9, 18454-18479. [CrossRef]

184. Fatima, N.; Shen, Y.; Crassini, K.; Iwanowicz, E.J.; Lang, H.; Karanewsky, D.S.; Christopherson, R.I.; Mulligan, S.P.; Best, O.G. The ClpP activator ONC-212 (TR-31) inhibits BCL2 and B-cell receptor signaling in CLL. eJHaem 2021. [CrossRef]

185. Graves, P.R.; Aponte-Collazo, L.J.; Fennell, E.M.J.; Graves, A.C.; Hale, A.E.; Dicheva, N.; Herring, L.E.; Gilbert, T.S.K.; East, M.P.; McDonald, I.M.; et al. Mitochondrial Protease ClpP is a Target for the Anticancer Compounds ONC201 and Related Analogues. ACS Chem. Biol. 2019, 14, 1020-1029. [CrossRef]

186. Madhukar, N.S.; Khade, P.K.; Huang, L.; Gayvert, K.; Galletti, G.; Stogniew, M.; Allen, J.E.; Giannakakou, P.; Elemento, O. A Bayesian machine learning approach for drug target identification using diverse data types. Nat. Commun. 2019, 10. [CrossRef]

187. Prabhu, V.V.; Madhukar, N.S.; Gilvary, C.; Kline, C.L.B.; Oster, S.; El-Deiry, W.S.; Elemento, O.; Doherty, F.; Vanengelenburg, A.; Durrant, J.; et al. Dopamine Receptor D5 is a Modulator of Tumor Response to Dopamine Receptor D2 Antagonism. Clin. Cancer Res. 2019, 25, 2305-2313. [CrossRef]

188. Kline, C.L.B.; Ralff, M.D.; Lulla, A.R.; Wagner, J.M.; Abbosh, P.H.; Dicker, D.T.; Allen, J.E.; El-Deiry, W.S. Role of Dopamine Receptors in the Anticancer Activity of ONC201. Neoplasia 2018, 20, 80-91. [CrossRef] [PubMed]

189. Lee, Y.G.; Kim, H.W.; Nam, Y.; Shin, K.J.; Lee, Y.J.; Park, D.H.; Rhee, H.-W.; Seo, J.K.; Chae, Y.C. LONP1 and ClpP cooperatively regulate mitochondrial proteostasis for cancer cell survival. Oncogenesis 2021, 10. [CrossRef] 